\title{
Fabrication of nonfouling, bactericidal, and bacteria corpse release multifunctional surface through surface-initiated RAFT polymerization
}

This article was published in the following Dove Press journal:

International Journal of Nanomedicine

20 December 2016

Number of times this article has been viewed

\author{
Bailiang Wang ${ }^{1,2}$ \\ $\mathrm{Zi} \mathrm{Ye}{ }^{\prime}$ \\ Yihong Tang' \\ Yuemei Han' \\ Quankui Lin',2 \\ Huihua Liu ${ }^{2}$ \\ Hao Chen ${ }^{1,2}$ \\ Kaihui $\mathrm{Nan}^{1,2}$
}

'School of Ophthalmology and Optometry, Eye Hospital, Wenzhou Medical University, Wenzhou,

${ }^{2}$ Wenzhou Institute of Biomaterials and Engineering, Chinese Academy of Sciences, Wenzhou, People's Republic of China
Correspondence: Bailiang Wang School of Ophthalmology and Optometry, Eye Hospital, Wenzhou Medical University, Wenzhou 32500, People's Republic of China

Tel +86 577880 I 7524

Fax +86 57788067962

Email wangbailiang2006@aliyun.com

Kaihui Nan

School of Ophthalmology and Optometry, Eye Hospital, Wenzhou Medical University, Wenzhou 325027. People's Republic of China

Tel +86 57788017500

Fax +86 57788067962

Email nankh@163.com
Abstract: Infections after surgery or endophthalmitis are potentially blinding complications caused by bacterial adhesion and subsequent biofilm formation on the intraocular lens. Neither single-function anti-adhesion surface nor contacting killing surface can exhibit ideal antibacterial function. In this work, a novel (2-(dimethylamino)-ethyl methacrylate-co2-methacryloyloxyethyl phosphorylcholine) (p (DMAEMA-co-MPC)) brush was synthesized by "grafting from" method through reversible-addition fragmentation chain transfer polymerization. 1-Bromoheptane was used to quaternize the $\mathrm{p}$ (DMAEMA-co-MPC) brush coating and to endow the surface with bactericidal function. The success of the surface functionalization was confirmed by atomic force microscopy, water contact angle, and spectroscopic ellipsometry. The quaternary ammonium salt units were employed as efficient disinfection that can eliminate bacteria through contact killing, whereas the 2-methacryloyloxyethyl phosphorylcholine units were introduced to suppress unwanted nonspecific adsorption. The functionalized poly(dimethyl siloxane) surfaces showed efficiency in reducing bovine serum albumin adsorption and in inhibiting bacteria adhesion and biofilm formation. The copolymer brushes also demonstrated excellent bactericidal function against gram-positive (Staphylococcus aureus) bacteria measured by bacteria live/dead staining and shake-flask culture methods. The surface biocompatibility was evaluated by morphology and activity measurement with human lens epithelial cells in vitro. The achievement of the $\mathrm{p}$ (DMAEMA $\left.{ }^{+}-\mathrm{co}-\mathrm{MPC}\right)$ copolymer brush coating with nonfouling, bactericidal, and bacteria corpse release properties can be used to modify intraocular lenses.

Keywords: anti-fouling, poly(dimethylsiloxane), intraocular lenses, endophthalmitis, biofilms

\section{Introduction}

Implantation of intraocular lens (IOL) in cataract surgery may lead to infectious endophthalmitis, which is the most feared and common complication. ${ }^{1,2}$ Despite the enormous progress made in asepsis, microsurgical techniques, suture materials, prosthetic materials, and antibiotics, postoperative endophthalmitis continues to be a great threat to ophthalmology patient vision. ${ }^{3}$ The incidence of endophthalmitis after cataract removal and IOL implantation is estimated between $0.07 \%$ and $0.12 \%$ in the developed countries; in the developing nations, the situation is even worse. ${ }^{4,5}$ Although the incidence is not high, endophthalmitis is a significant postoperative morbidity after cataract surgery. Infections after IOL implantation affect more than $30 \%$ of patients, which lead to the major visual loss and result in up to $18 \%$ blindness. ${ }^{6,7}$ The grampositive coagulase-negative micrococcus Staphylococcus epidermidis is the most frequently cultured microorganism; however, Staphylococcus aureus and anaerobic species have also been implicated. ${ }^{8}$ 
Once bacteria adhere to the surface of implants and biomedical devices, bacterial colonies and biofilm will gradually form on the surfaces and damage the functionality of biomaterials. ${ }^{9}$ The adhesion of bacteria on the surface of implants is the first and key step that poses a big threat to the long-term success of the implants. ${ }^{10,11}$ The adhesion of bacteria is a very complicated process, and it basically includes two stages: 1) an initial, rapid, and reversible interaction and 2) a slowly irreversible adhesion through specific and nonspecific interactions. Once bacteria irreversibly adhere on the surface of the implant, it is very hard to remove them, which can grow and reproduce rapidly in the human nutrition environment. More seriously, adhered bacteria grow into biofilm through proliferation and secretion of extracellular matrix. Bacterial biofilm is composed of bacteria and exopolysaccharides, proteins, minerals, nutrients, and waste discharge channels. ${ }^{12-14}$ Unfortunately, the contaminated implants have to be extracted because there is no suitable treatment method to deal with the situation.

Many strategies have been developed to construct antibacterial surface to prevent the formation of biofilms. ${ }^{15-20}$ These antibacterial surfaces can be constructed through two different methods: anti-adhesive coating to resist bacterial adhesion and bactericidal surface to kill contacting bacteria. Many kinds of anti-adhesive coatings have been designed and prepared to reduce bacterial adhesion. ${ }^{21}$ The highly hydrophilic, nontoxic, and nonimmunogenic poly(ethylene glycol) ${ }^{22,23}$ polyvinylpyrrolidone, ${ }^{24,25}$ heparin, ${ }^{26}$ and zwitterionic polymers such as sulfobetaine ${ }^{27}$ and poly (2-methacryloyloxyethyl phosphorylcholine $)^{28-30}$ are the most commonly used polymers to resist nonspecific protein adsorption and bacterial adhesion. 2-methacryloyloxyethyl phosphorylcholine (MPC) is a zwitterionic monomer consisting of a biomimetic phosphorylcholine group. Copolymer coatings composed of MPC have excellent biocompatibility, showing nonbiofouling property and anti-thrombogenicity. Antibacterial agents such as quaternary ammonium salts, antibacterial peptides, chitosan, and phosphonium salts can be prepared onto biomaterial surface and exert highly efficient bactericidal function through contact killing. However, general polycation bactericidal surface hardly can release bacteria corpse to restore and maintain efficient bactericidal function. Negatively charged bacterial surface can easily adhere to positively charged polycations surfaces. Furthermore, leaving bacteria corpse on the surface is very beneficial to bacterial adhesion, again making the situation even worse. On the other hand, nonfouling surface always does not have bactericidal function. Therefore, it is very urgent to design a smart antibacterial surface that possesses both very efficient bactericidal function and the ability to release bacteria corpse. In this way, early after implantation, the combined coating can exert nonfouling function to resist protein and bacterial adhesion. In a long way, once bacteria adhere on the biomaterials, they can be sterilized by bactericidal component through contacting killing. More importantly, bacteria corpse can be released from the implant surface through the molecular chain movement of the strong hydrophilic component.

Poly(dimethyl siloxane) (PDMS) is commonly used as an IOL material because it is nontoxic, stable, and inert to body fluids. ${ }^{31}$ However, the highly hydrophobic nature often leads to the adhesion of bacteria, proteins, and biomolecules on the silicone surface. So, it is imperative to modify PDMS surface into hydrophilic surface to enhance its anti-adhesion function. Preparation of polymer brushes is an effective approach to modify the surface of biomaterials that can be constructed through either "grafting onto" or "grafting from" method. ${ }^{32}$ There are two main advantages of this approach: 1) surface properties can be tuned through changing the component of the polymer brushes and 2) the high mechanical and chemical robustness can lead to long-term stability. In comparison, high grafting density on the surface usually can be used to initiate the "grafting from" polymerization and high thickness coating can be obtained through this approach. ${ }^{33,34}$ In comparison, reversible addition-fragmentation chain transfer (RAFT) polymerization is suitable to initiate and graft conventional radical polymerization monomers on the surface of substrates, which is considered promising for surface modification. ${ }^{35,36}$

In this work, we aimed to construct (2-(dimethylamino)ethyl methacrylate-co-2-methacryloyloxyethyl phosphorylcholine) (p (DMAEMA ${ }^{+}$-co-MPC)) copolymer brush coating on the surface of PDMS IOL to enhance the nonfouling and antibacterial properties. As shown in Scheme 1, the synthesis of brushes was carried out through the RAFT polymerization method. Spectroscopic ellipsometry, atomic force microscopy (AFM), and water contact angle (WCA) analyses were used to characterize each step of modification. Both live/dead staining method and shake-flask culture test were carried out to evaluate the antibacterial properties of the obtained coating on PDMS. Cell counting kit-8 assays (CCK-8) and fluorescein diacetate (FDA) were used to explore the cell compatibility and nonfouling property of the $\mathrm{p}$ (DMAEMA ${ }^{+}$ co-MPC) brush coating toward human lens epithelial cells (HLECs). The obtained $\mathrm{p}$ (DMAEMA+-co-MPC) brush coating with nonfouling and excellent antibacterial activities could be widely used for biomaterial surface modification. 


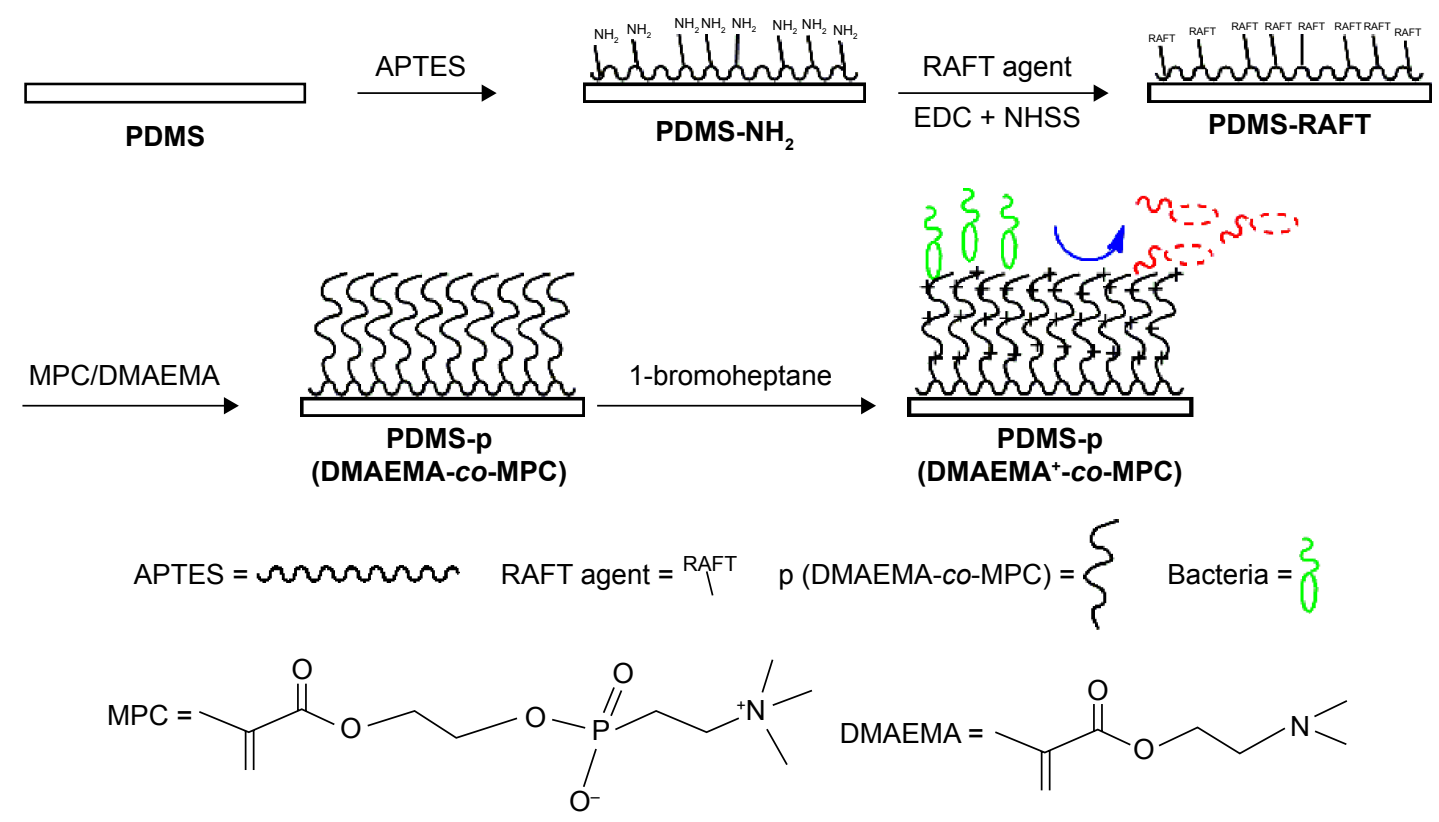

Scheme I Schematic illustration of the preparation of $P$ (DMAEMA+-co-MPC) copolymer brushes on PDMS with nonfouling and bactericidal properties. Abbreviations: P (DMAEMA+-co-MPC), (2-(dimethylamino)-ethyl methacrylate-co-2-methacryloyloxyethyl phosphorylcholine); PDMS, poly(dimethyl siloxane); RAFT, reversible addition-fragmentation chain transfer; APTES, (3-Aminopropyl)triethoxysilane; MPC, 2-methacryloyloxyethyl phosphorylcholine; DMAEMA, 2-(dimethylamino)ethyl methacrylate.

\section{Materials and methods Materials and reagents}

4,4'-Azobis-(4-cyanovaleric acid) (V501), 4-cyano-4(phenylcarbonothioylthio) pentanoic acid (RAFT agent), poly(ethyleneimine) (branched PEI, molecular weight: $25 \mathrm{kDa}$ ), NHSS, and EDC were purchased from SigmaAldrich Co., St Louis, MO, USA. Sylgard ${ }^{\circledR} 184$ from Dow Corning was used to prepare PDMS, which was cured for 12 hours using curing agent and elastomer base in the ratio of 10:1. Trypticase soy broth and trypticase soy agar were obtained from Hangzhou Baisi Corporation. A Millipore Milli-Q system (Millipore, Billerica, MA, USA) was used to produce ultrapure distilled water.

\section{Pretreatment of the substrates}

The PDMS substrates were cut into a certain shape $\left(2 \times 1 \mathrm{~cm}^{2}\right)$, cleaned with ethanol and water, respectively, for 10 minutes. The substrates were dried under a gentle stream of nitrogen gas and immersed in PEI solution $(5 \mathrm{mg} / \mathrm{mL})$ to form a precursor layer $\left(2\right.$ hours, $25^{\circ} \mathrm{C}$ ). Next, the PDMS sheets were cleaned with water and dried using $\mathrm{N}_{2}$.

\section{Synthesis of $\mathrm{p}$ (DMAEMA ${ }^{+}$-co-MPC) copolymer brushes}

The RAFT polymerization method was used to construct the $\mathrm{p}$ (DMAEMA ${ }^{+}-\mathrm{Co}$-MPC) copolymer brush coatings on the PDMS substrates. ${ }^{37}$ To immobilize the RAFT agent on the aminolysized PDMS, EDC (10 mmol), NHSS (20 mmol), and RAFT agent $(0.0234 \mathrm{mmol})$ were successively added into 2-(N-Morpholino)ethanesulfonic acid buffer (0.1 M, pH 5.5) with magnetic stirring for 12 hours. P (DMAEMA ${ }^{+}$-coMPC) copolymer brush coatings were synthesized by RAFT polymerization in DMAEMA ${ }^{+} / \mathrm{MPC}$ monomer solution in ethanol in the mass ratio of 1:0, 1:0.1, 1:0.25, and 1:0.5 and the obtained samples were named as P1-0, P1-0.1, P1-0.25 and P1-0.5, respectively.

The $\mathrm{p}$ (DMAEMA ${ }^{+}-c o-0.50$ MPC) brush coatings were typically synthesized as following: V501 (2 mg), DMAEMA $(150 \mathrm{mg})$, and MPC $(150 \mathrm{mg})$ were dissolved in $3 \mathrm{~mL}$ ethanol under a $\mathrm{N}_{2}$ atmosphere in $5 \mathrm{~mL}$ bottles. To initiate the polymerization, the temperature was elevated to $60^{\circ} \mathrm{C}$ and the mixture was stirred with a magneton for 24 hours. After reaction, ethanol was used to wash the samples three times. 1-Bromoheptane $(25 \mathrm{v} \%)$ in ethanol was used to quaternize the surface-grafted brushes into PQA at room temperature for 12 hours. Then, the PDMS substrates were washed with ethanol three times and dried in vacuum at $30^{\circ} \mathrm{C}$ for 24 hours.

\section{Surface characterizations}

\section{Surface morphology}

AFM (SPA 400; Seiko Instruments Inc.) was applied to measure the surface morphology of the surfaces. Under ambient conditions, a commercial scanning probe microscopy was carried out to obtain the AFM images in the tapping mode, in 
which a silicon cantilever, nanosensor, was equipped under typical spring constant of $40 \mathrm{Nm}^{-1}$.

\section{Surface hydrophilicity}

Drop shape analysis (KRÜSS, DSA10-MK2) was applied to explore the surface hydrophilicity of the brush by sessile dropping method. A $20 \mu \mathrm{L}$ ultrapure water droplet dropped and contacted with the surface, a photograph was taken within 15 seconds. Built-in software and microscope provided by manufacturer were used to calculate the contact angle formed between the droplet and the surface.

\section{Thickness measurement}

Thickness changes in the process of PEI pretreating, RAFT agent grafting, and RAFT polymerization were measured by spectroscopic ellipsometry (M-2000 DITM; J.A. Woollam Co.). Silicon wafers were used as substrates in this measurement instead of PDMS sheets. The set parameters and test procedures were as follows: the wavelength ranged from 124 to $1,700 \mathrm{~nm}$ and both $65^{\circ}$ and $70^{\circ}$ were used as the angle of incidence. For data analysis, $\Delta$ and $\Psi$ values were set at wavelength ranging from 600 to $1,700 \mathrm{~nm}$. The thickness of multilayer films was determined using Cauchy model with $A_{n}$ and $B_{n}$ as fit parameters set at 1.45 and 0.01 , respectively. Then, the thickness of the multilayer films could be automatically calculated.

\section{Molecular weight measurement}

The molecular weight of grafted brushes on the surface could not be directly measured. To learn about the chain length information, an indirect way was used to evaluate the molecular weight of the brushes under the same conditions. An appropriate amount of initiator was put into the solution and polymerization was initiated. Waters gel permeation chromatography (GPC) system equipped with a set of Waters Styragel columns was used to perform the GPC measurements. Both Waters-2414 refractive index detector and Waters-2487 dual $\lambda$ absorbance detector were used in the columns. The diluent was HPLC grade THF, and the flow rate was low $(1.0 \mathrm{~mL} / \mathrm{min})$. A series of polystyrene standards with near-monodisperse was used for the calibration.

\section{Surface elemental analysis}

The X-ray photoelectron spectroscopy (XPS) spectrum was used to detect the surface elementals of the top surfaces. Al Ko excitation radiation $(1,486.6 \mathrm{eV})$ was employed and recorded on a PHI 5300 ESCA System (PerkinElmer, Waltham, MA, USA). A take-off angle of $45^{\circ}$ was used in the measurement. The power worked at $250 \mathrm{~W}(12.5 \mathrm{kV})$ was applied as the X-ray source. The binding energy ranging from 0 to $1,000 \mathrm{eV}$ was run in the survey spectra to collect high-resolution spectra.

\section{Cytotoxicity assays}

\section{Cell cultivation}

The Dulbecco's Modified Eagle's Medium/F12 (1:1) cell culture medium containing 10\% fetal bovine serum, $100 \mathrm{U} / \mathrm{mL}$ penicillin, and $100 \mu \mathrm{g} / \mathrm{mL}$ streptomycin was used to incubate the HLECs (ATCC, SRA01/04) in a 5\% $\mathrm{CO}_{2}$ incubator at $37^{\circ} \mathrm{C}$. Confluent cells were digested to harvest the cells using $0.25 \%$ trypsin and $0.02 \%$ EDTA, followed by centrifugation $(1,000 \times g$ for 3 minutes $)$. Then, the cell concentration was calculated using hemocytometer and resuspended for incubation on the surfaces of materials. The HLECs with a density of $1.0 \times 10^{4}$ cells per sample were cultivated with the specimens in 96-well tissue culture plates for 24 hours. Subsequently, the viability and morphology studies of HELCs on the samples were measured by FDA and CCK- 8 methods. ${ }^{38,39}$

\section{Cell viability}

In this experiment, CCK-8 (Beyotime, Haimen, People's Republic of China) assay was employed to quantitatively evaluate the cell viability of multilayer films toward HLECs. After inoculating for 24 hours, the HLECs were replaced by $100 \mu \mathrm{L} \mathrm{10 \%}$ fetal bovine serum Dulbecco's Modified Eagle's Medium/F12 (1:1) mixed medium containing $10 \mu \mathrm{L}$ CCK-8. The mixed medium was incubated to form water dissoluble formazan at $37^{\circ} \mathrm{C}$ for 2 hours. Then, $100 \mu \mathrm{L}$ of the formazan solution was aspirated from each sample with a pipette and added to a new 96-well plate. The absorbance at $450 \mathrm{~nm}$ (calibrated wave) was examined using a microplate reader (Multiskan MK33; Thermo Electron Corporation, Shanghai, People's Republic of China). Tissue culture plates (TCPS) without any modified films were used as control and six parallel replicates were prepared.

\section{Cell morphology}

Stock FDA solutions $(5.0 \mathrm{mg} / \mathrm{mL})$ were prepared by dissolving FDA in acetone. The working solution with the concentration of $5.0 \mu \mathrm{g} / \mathrm{mL}$ was freshly prepared by adding FDA stock solution into $0.1 \mathrm{M}$ phosphate-buffered saline (PBS). The membrane integrity and cytoplasmic esterase activity of cells on the surface could be examined using FDA (Sigma-Aldrich Co.) as indicator for fluorescence microscope investigation (Carl Zeiss Meditec AG, Jena, Germany) at 10× magnification in fluorescein filter, $488 \mathrm{~nm}$ excitation. After incubation with the specimens in the 96-well tissue culture plate for 24 hours, FDA solution $(20 \mu \mathrm{L})$ was added into the HLEC solution and incubated for 5 minutes. After washing with PBS twice, fluorescence microscopy examination was performed at the wavelength of $488 \mathrm{~nm}$ for each sample. TCPS that did not contain samples were used as controls. 


\section{Protein adsorption test}

Bovine serum albumin (BSA) adsorption test was performed to estimate the anti-adhesive effect of brush coatings using a bicinchoninic acid protein assay kit (Beyotime). Firstly, the $0.5 \mathrm{mg} / \mathrm{mL}$ BSA solution was prepared by diluting the standard solution $(5.0 \mathrm{mg} / \mathrm{mL})$ in the PBS solution. The BSA protein was incubated with the coating modified and pristine PDMS in a 96-well plate for 2 hours. Then, the loosely bound protein layer was removed by rinsing the sheets in a rectangular chamber containing distilled water for 1 minute. After washing with distilled water to remove the loosely bound protein, each well of a 96-well plate was injected with $0.2 \mathrm{~mL}$ bicinchoninic acid working solution. The microplate reader (Multiskan MK33; Thermo Electron Corporation) was used to measure the absorbance at $570 \mathrm{~nm}$ after incubation for 30 minutes at $37^{\circ} \mathrm{C}$.

\section{Antibacterial tests in vitro}

Both bacteria live/dead staining and shake-flask culture methods were carried out to measure the antimicrobial activities of brushes coatings using $S$. aureus (ATCC 6538) as the model bacteria.

The shake-flask culture method was performed to investigate the sterilization rate of the $\mathrm{p}\left(\mathrm{DMAEMA}^{+}-\mathrm{co}-\mathrm{MPC}\right)$ copolymer brush coatings. The coating modified and pristine PDMS sheets were incubated with $S$. aureus suspension $\left(1.1 \times 10^{5}\right.$ colony forming units $\left./ \mathrm{mL}, 10 \mathrm{~mL}\right)$ in test tubes.
The bacterial suspension was pipetted out at the predetermined time and was diluted with PBS buffer. In all, $0.2 \mathrm{~mL}$ of the solution was plated onto the solid agar and incubated for 24 hours before counting the number of viable bacteria. The percentage of viable bacteria in the suspension relative to the initial number of bacteria was defined as survival ratio.

Furthermore, bacterial adhesion and viability were also determined using the LIVE/DEAD BacLight bacterial viability kit (L-7012; Invitrogen). For this method, bacterial structural integrity on the surfaces of live or dead cells could be evaluated. Before testing, $10 \mathrm{~mL}$ of $1.0 \times 10^{5}$ cells $/ \mathrm{mL} S$. aureus suspensions in PBS was incubated with the antibacterial coating modified and pristine PDMS for 15 seconds, 24 hours, and 72 hours. After being stained according to the kit protocol and washing, the PDMS sheets were kept in the dark and observed by fluorescence microscope investigation (Carl Zeiss).

All data were obtained from at least three independent experiments with five parallel samples and expressed as mean \pm standard deviation and typical images.

\section{Results and discussion \\ Fabrication and characterizations of the copolymer brushes}

As shown in Figure 1, the copolymer brushes were synthesized through four-step reactions. The PDMS surfaces were endowed with primary amine groups using PEI pretreatment in the first

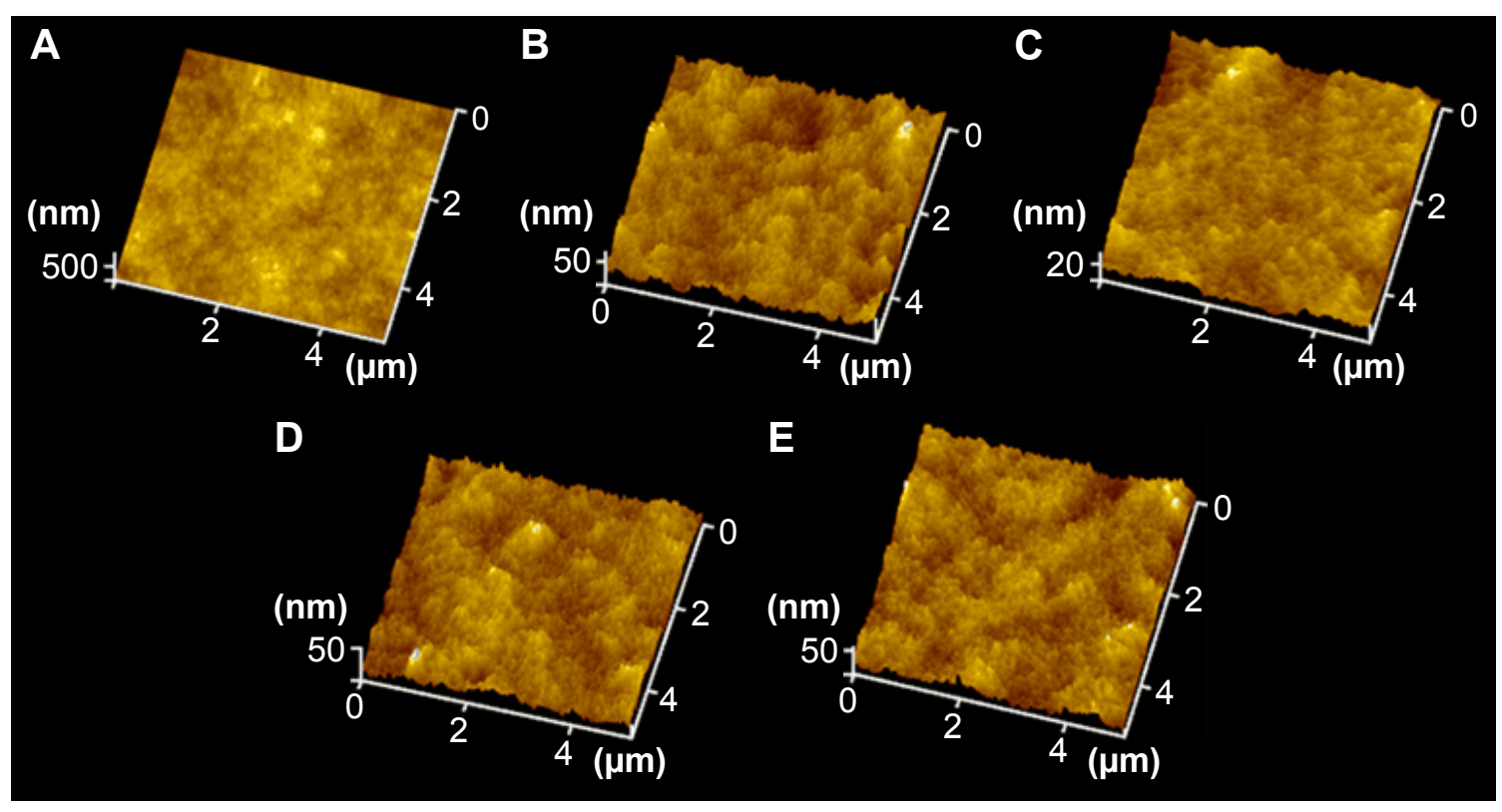

Figure I AFM images on various surfaces.

Notes: (A) Pristine PDMS, (B) p (DMAEMA ${ }^{+}$), (C) p (DMAEMA+'-co-0.10 MPC), (D) p (DMAEMA+-co-0.25 MPC), and (E) p (DMAEMA+-co-0.50 MPC). P (DMAEMA+-coMPC) copolymer brush coatings were synthesized by RAFT polymerization in DMAEMA $/$ MPC monomer solution in ethanol in the mass ratio of $1: 0$, I:0.1, I:0.25, and I:0.5 and the obtained samples were named as $\mathrm{PI}-0, \mathrm{PI}-0 . \mathrm{I}, \mathrm{PI}-0.25$ and $\mathrm{PI}-0.5$, respectively.

Abbreviations: AFM, atomic force microscopy; PDMS, poly(dimethyl siloxane); P (DMAEMA+-co-MPC), (2-(dimethylamino)-ethyl methacrylate-co-2-methacryloyloxyethyl phosphorylcholine); MPC, 2-methacryloyloxyethyl phosphorylcholine; DMAEMA, 2-(dimethylamino)-ethyl methacrylate; RAFT, reversible addition-fragmentation chain transfer. 
step. In the second step, by reaction with NHSS and EDC covalent binding of RAFT agent containing - $\mathrm{COOH}$ groups was achieved to generate an initiator layer on the PDMS with $-\mathrm{NH}_{2}$ groups. RAFT polymerization was then performed from the initiator-modified surfaces. The third step involved the copolymerization of MPC and DMAEMA monomer surfaceinitiated RAFT from the PDMS surface to generate copolymer brushes. In the final step, 1-bromoheptane was used to quaternize the $\mathrm{p}$ (DMAEMA ${ }^{+}-\mathrm{co}$-MPC) copolymer brush coatings with bactericidal function. Each step was characterized by WCA, spectroscopic ellipsometry, and AFM to confirm that the reaction proceeded smoothly. As shown in Table 1, WCA of PDMS was at $116.0^{\circ} \pm 3.7^{\circ}$ showing high hydrophobicity and it changed to $55.2^{\circ} \pm 2.4^{\circ}$ after PEI treatment showing apparent hydrophilicity. However, the RAFT macroinitiator coating had WCA at $92.3^{\circ} \pm 4.2^{\circ}$ exhibiting hydrophobicity.

To measure the coating thickness growing on the substrates, spectroscopic ellipsometry measurement was carried out with the accuracy to the nanoscale. As shown in Table 1, the thickness of PEI was $1.8 \pm 0.3 \mathrm{~nm}$, which indicated the success of pretreatment. Then, the thickness increased to $2.5 \pm 0.4 \mathrm{~nm}$ after grafting of the RAFT agent. After grafting of the copolymer brush coatings, the thickness gradually increased to $25 \mathrm{~nm}$ deducting thickness of PEI and the RAFT agent. The thickness of self-assembly monolayer or physically adsorbed film is impossible to achieve such a thick thickness. ${ }^{40-42}$ So, the "grafting from" method through RAFT polymerization is suitable to construct copolymer brush coating to modify biomaterials. Apart from hydrophilicity, topography ${ }^{43,44}$ change is another important factor affecting the anti-adhesion properties of the material surface. As shown in Table 1 and Figure 1 the surfaces of PEI and the RAFT agent were smooth, which nearly changed on the surface in the pretreatment with low the root mean square (RMS) roughness (2.06 \pm 0.32 and $3.42 \pm 0.41 \mathrm{~nm}$, respectively). As shown in Figure 1, the height and number of the peaks on the surface were clearly illustrated by the AFM three-dimensional images. The RMS roughness $\left(5 \times 5 \mu \mathrm{m}^{2}\right)$ of the $\mathrm{p}\left(\mathrm{DMAEMA}^{+}\right)$ brush coatings was $3.16 \pm 0.31 \mathrm{~nm}$, which indicated no apparent difference with $\mathrm{p}$ (DMAEMA $\left.{ }^{+}-c o-\mathrm{MPC}\right)$ copolymer brush coatings. It could be concluded that the surface of copolymer brush coating was uniform and smooth with low RMS, which also indicated the successful preparation of $\mathrm{p}\left(\mathrm{DMAEMA}^{+}-\right.$ co-MPC) brush coatings on PDMS.

XPS with a higher precision for the analysis of elemental composition was used to test the obtained brushes. Pristine PDMS consisted mainly of carbon, oxygen, and silicon elements. BEs of four XPS peaks at 532, 284, 102, and $152 \mathrm{eV}$ attributed to $\mathrm{O} 1 \mathrm{~s}, \mathrm{C} 1 \mathrm{~s}, \mathrm{Si} 2 \mathrm{p}$, and $\mathrm{Si} 2 \mathrm{~s}$ core level signals, respectively, which were discernible in the PDMS surface wide scan spectrum (Figure 2A). However, there was neither peak around $400 \mathrm{eV}$ nor around $134 \mathrm{eV}$ showing no $\mathrm{N}$ and $\mathrm{P}$ elements on PDMS surface (Figure $2 \mathrm{~B}$ and $\mathrm{C}$ ). After being grafted by $\mathrm{p}\left(\mathrm{DMAEMA}^{+}\right.$) brush (Figure 2D-F), the $\mathrm{N}$ 1s core level spectrum showed an additional peak at the $\mathrm{BE}$ of $\sim 401 \mathrm{eV}$, attributable to the $\mathrm{N} 1$ s core level signals of $\mathrm{C}-\mathrm{N}^{+}$species, indicating the successful fabrication of $\mathrm{p}\left(\mathrm{DMAEMA}^{+}\right)$brushes on the PDMS surface. Furthermore, core level signals of $\mathrm{C} 1 \mathrm{~s}$ and $\mathrm{O} 1 \mathrm{~s}$, a new peak with $\mathrm{BE}$ at $131 \mathrm{eV}$ indicating core level signal of $\mathrm{P} 2 \mathrm{p}$, which was discernible in the wide and $\mathrm{P} 2 \mathrm{p}$ spans of the $\mathrm{p}$ (DMAEMA $\left.{ }^{+}-\mathrm{co}-\mathrm{MPC}\right)$ copolymer brushes modified PDMS surface (Figure $2 \mathrm{G}-\mathrm{I}$ ). It showed the existing MPC units in the $\mathrm{p}$ (DMAEMA ${ }^{+}-\mathrm{co}$-MPC) brush coating. XPS can only detect a thickness ranging from 1 to $10 \mathrm{~nm} .{ }^{45}$ After grafting of brush coating, no Si core level signals had been detected, which confirmed the thickness measured by spectroscopic ellipsometry (more than $25 \mathrm{~nm}$ ). It could be concluded that $\mathrm{p}$ (DMAEMA ${ }^{+}-\mathrm{D} O$-MPC) copolymer brushes had been successfully constructed on PDMS surfaces.

The areas of the curves were used to calculate the relative proportions of $\mathrm{C} / \mathrm{O} / \mathrm{N} / \mathrm{P} / \mathrm{Si}$ (74.1/17.6/8.3/-/-, atom $\%$ ), respectively, which agreed favorably with the theoretical values calculated in $\mathrm{p}\left(\mathrm{DMAEMA}^{+}\right)$. The growth of the $\mathrm{p}\left(\mathrm{DMAEMA}^{+}\right)$brushes on PDMS was responsible for the appearance of the nitrogen peak. As shown in Table 2, the element ratio experimentally measured for

Table I A summary of the various characteristics of $p$ (DMAEMA ${ }^{+}$-co-MPC) copolymer brush coating

\begin{tabular}{llllllll}
\hline Test method & PDMS & APTES & RAFT agent & P (DMAEMA $\left.{ }^{+}\right)$ & $\begin{array}{l}\text { P (DMAEMA } \\
\text { co-0.10 MPC) }\end{array}$ & $\begin{array}{l}\text { P (DMAEMA+- } \\
\text { co-0.25 MPC) }\end{array}$ & $\begin{array}{l}\text { P (DMAEMA } \\
\text { co-0.50 MPC) }\end{array}$ \\
\hline Static contact angle $\left(^{\circ}\right)$ & $116.0 \pm 3.7$ & $55.2 \pm 2.4$ & $92.3 \pm 4.2$ & $75.1 \pm 1.6$ & $59.6 \pm 2.5$ & $48.1 \pm 3.3$ & $34.4 \pm 2.4$ \\
Thickness* $(\mathrm{nm})$ & NA & $1.8 \pm 0.3$ & $2.5 \pm 0.4$ & $29.4 \pm 0.6$ & $27.4 \pm 0.6$ & $26.4 \pm 0.7$ & $28.6 \pm 0.6$ \\
RMS $(\mathrm{nm})$ & $2.78 \pm 0.26$ & $2.06 \pm 0.32$ & $3.42 \pm 0.41$ & $3.16 \pm 0.31$ & $3.32 \pm 0.27$ & $2.88 \pm 0.47$ & $3.48 \pm 0.35$ \\
\hline
\end{tabular}

Notes: *Thickness measurement was done on silicon wafer. Data are presented as mean \pm standard deviation. P (DMAEMA+-coMPC) copolymer brush coatings were synthesized by RAFT polymerization in DMAEMA ${ }^{+} /$MPC monomer solution in ethanol in the mass ratio of I:0, I:0.1, I:0.25, and I:0.5 and the obtained samples were named as $\mathrm{PI}-0, \mathrm{PI}-0 . \mathrm{I}, \mathrm{PI}-0.25$ and $\mathrm{PI}-0.5$, respectively.

Abbreviations: P (DMAEMA+-co-MPC), (2-(dimethylamino)-ethyl methacrylate-co-2-methacryloyloxyethyl phosphorylcholine); PDMS, poly(dimethyl siloxane); RAFT, reversible addition-fragmentation chain transfer; NA, not available; RMS, root mean square; APTES, (3-Aminopropyl)triethoxysilane; MPC, 2-methacryloyloxyethyl phosphorylcholine; DMAEMA, 2-(dimethylamino)-ethyl methacrylate. 

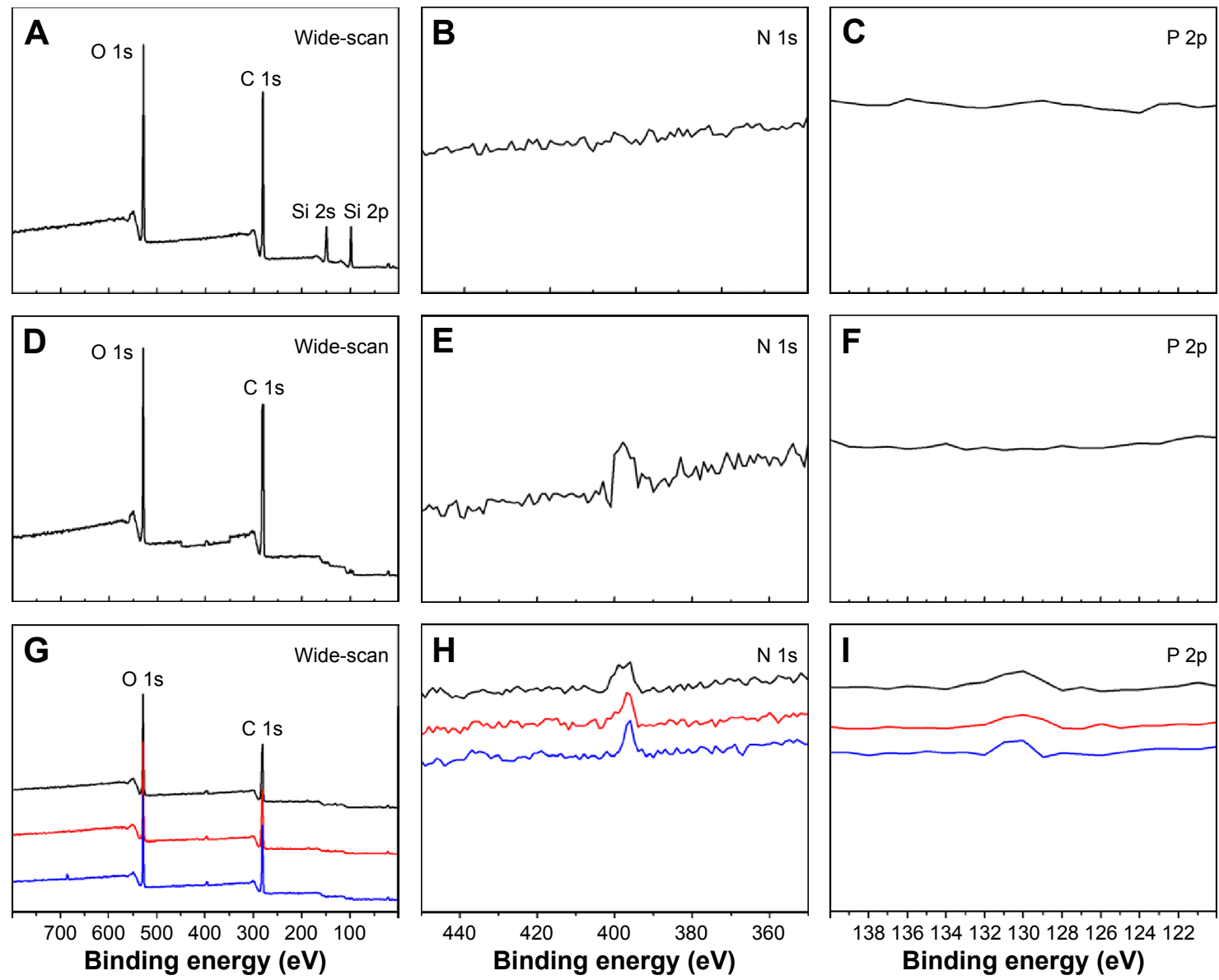

Binding energy (eV)

Binding energy (eV)

$$
-p\left(D_{M A E M A}^{+}-c o-0.10 \mathrm{MPC}\right)-\mathrm{p}\left(\mathrm{DMAEMA}^{+}-c o-0.25 \mathrm{MPC}\right)-\mathrm{p}\left(\mathrm{DMAEMA}^{+}-c o-0.50 \mathrm{MPC}\right)
$$

Figure 2 XPS spectra collected from PDMS surface (A) wide-scan spectra, (B) PDMS surface N Is core-level spectra, (C) PDMS surface P 2p core-level spectra. P (DMAEMA ${ }^{+}$)-modified PDMS (D) wide-scan spectra, (E) N Is core-level spectra, (F) P 2p core-level spectra. P (DMAEMA ${ }^{+}$-co-0.25 MPC)-modified PDMS (G) wide-scan spectra, (H) N Is core-level spectra, and (I) P 2p core-level spectra.

Abbreviations: XPS, X-ray photoelectron spectroscopy; PDMS, poly(dimethyl siloxane); P (DMAEMA + -co-MPC), (2-(dimethylamino)-ethyl methacrylate-co-2methacryloyloxyethyl phosphorylcholine); MPC, 2-methacryloyloxyethyl phosphorylcholine; DMAEMA, 2-(dimethylamino)-ethyl methacrylate.

p (DMAEMA+-co-MPC) copolymer brushes and PDMS was consistent with the theoretical values. Furthermore, GPC measurement was carried out to determine the relative molecular weight and polydispersity index $(\mathrm{PDI}=\mathrm{Mw} / \mathrm{Mn})$ of the copolymer brushes (Table 2). The molecular weight and PDI of p (DMAEMA+-co-0.25 MPC) copolymer brushes were 45 100/25 $700 \mathrm{~g} / \mathrm{mol}(\mathrm{Mw} / \mathrm{Mn})$ and 1.75, which was as a typical product of RAFT polymerization. As shown in Figure 3, the GPC profile distribution of molecular weight of the copolymer had a monomodal peak, which proved the high purity of tested samples. What is more, it indicated that the construction of the copolymer brushes of MPC and

Table 2 Element composition (atomic\%) and molecular weight of the brushes on the PDMS surface determined by XPS and GPC

\begin{tabular}{|c|c|c|c|c|c|}
\hline Species analyzed & PDMS & p (DMAEMA') & $\begin{array}{l}\text { P (DMAEMA+- } \\
\text { co-0.10 MPC) }\end{array}$ & $\begin{array}{l}\text { P (DMAEMA+- } \\
\text { co-0.25 MPC) }\end{array}$ & $\begin{array}{l}\text { p (DMAEMA+- } \\
\text { co-0.50 MPC) }\end{array}$ \\
\hline $\begin{array}{l}\mathrm{C} / \mathrm{O} / \mathrm{N} / \mathrm{P} / \mathrm{Si} \\
\text { (theoretical) }\end{array}$ & $50.0 / 25.0 /-/ 25.0$ & 72.7/18.2/9.1/-1- & $70.8 / 19.5 / 8.7 / 0.5 /-$ & $68.6 / 21.6 / 8.2 / 1.3 /-$ & 65.1/24.9/7.2/2.7/- \\
\hline $\begin{array}{l}\mathrm{C} / \mathrm{O} / \mathrm{N} / \mathrm{P} / \mathrm{Si} \\
\text { (experimental) }\end{array}$ & $53.8 / 19.0 /-/ 27.2$ & 74.1/17.6/8.3/-1- & 68.7/21.3/9.1/0.9/- & 66.7/21.9/9.6/1.8/- & $62.6 / 25.3 / 8.5 / 3.6 /-$ \\
\hline $\operatorname{Mn}\left(\times 10^{3}\right)$ & - & 23.6 & 26.9 & 25.7 & 28.2 \\
\hline $\operatorname{Mw}\left(\times 10^{3}\right)$ & - & 38.3 & 41.8 & 45.1 & 46.3 \\
\hline PDI & - & 1.62 & 1.55 & 1.75 & 1.64 \\
\hline
\end{tabular}

Abbreviations: PDMS, poly(dimethyl siloxane); XPS, X-ray photoelectron spectroscopy; P (DMAEMA+-co-MPC), (2-(dimethylamino)-ethyl methacrylate-co-2-methacryloyloxyethyl phosphorylcholine); GPC, gel permeation chromatography; PDI, polydispersity index; MPC, 2-methacryloyloxyethyl phosphorylcholine; DMAEMA, 2-(dimethylamino)-ethyl methacrylate; Mw, weight-average molecular weight; Mn, number-average molecular weight. 


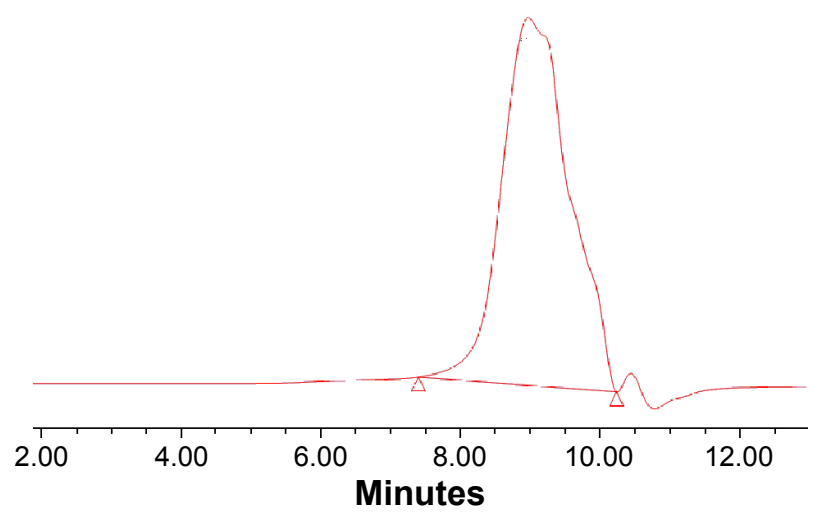

Figure 3 GPC chromatogram of $p$ (DMAEMA ${ }^{+}-c 0-0.25$ MPC) copolymer. Abbreviations: $\mathrm{p}$ (DMAEMA ${ }^{+}$-co-MPC), (2-(dimethylamino)-ethyl methacrylate-co2-methacryloyloxyethyl phosphorylcholine); GPC, gel permeation chromatography; MPC, 2-methacryloyloxyethyl phosphorylcholine; DMAEMA, 2-(dimethylamino)ethyl methacrylate.

DMAEMA was in a controlled way through RAFT polymerization with PDI less than 1.8 .

\section{Nonfouling activity against protein adsorption}

On contact with human body fluid, nonspecific protein adsorption occurs on almost all implants, which can cause bacterial infections, immune response, and thrombus formations. ${ }^{46}$ As model protein, BSA was used to assess the nonfouling property against nonspecific protein absorption of the coating surfaces. The results showed that BSA was extensively adsorbed on the PDMS and p (DMAEMA ${ }^{+}$) brush coating-modified PDMS (Figure 4). It demonstrated that strong interactions existed between protein and these two kinds of surfaces. It is worth noting that the $\mathrm{p}\left(\mathrm{DMAEMA}^{+}-\mathrm{co}-\mathrm{MPC}\right)$ copolymer

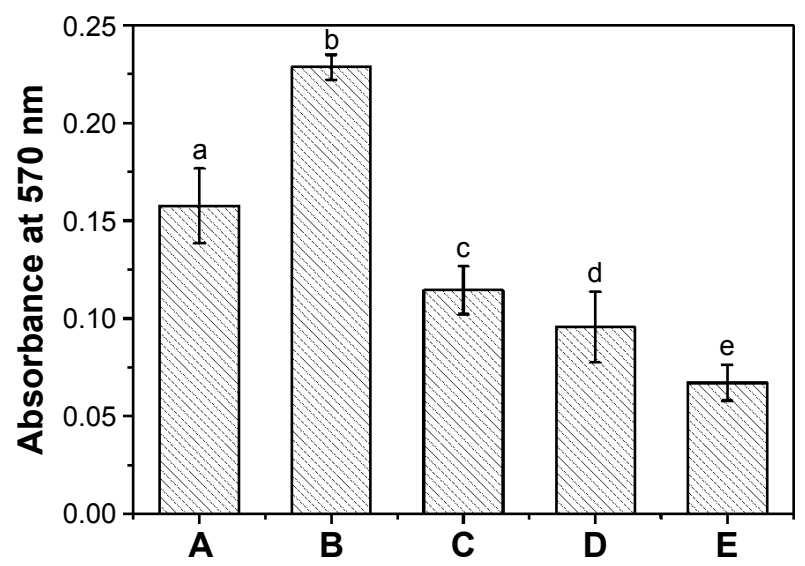

Figure 4 BSA adsorption.

Notes: (A) Pristine PDMS, (B) p (DMAEMA $\left.{ }^{+}\right),\left(\right.$C) p (DMAEMA ${ }^{+}-$co-0.10 MPC), (D) $P$ (DMAEMA ${ }^{+}-c 0-0.25$ MPC), and (E) $P$ (DMAEMA ${ }^{+}-c 0-0.50$ MPC)-modified PDMS. The statistical significance is indicated by different letters $(P<0.05)$.

Abbreviations: BSA, bovine serum albumin; PDMS, poly(dimethyl siloxane); P (DMAEMA+-co-MPC), (2-(dimethylamino)-ethyl methacrylate-co-2-methacryloyloxyethyl phosphorylcholine); MPC, 2-methacryloyloxyethyl phosphorylcholine; DMAEMA, 2-(dimethylamino)-ethyl methacrylate. brush coatings were effective in reducing BSA absorption. Moreover, the nonfouling effect toward BSA obviously increased as the amount of MPC increased from 10-50 wt \%. When the MPC content was $10 \mathrm{wt} \%$ in the copolymer brush, the adsorption of BSA dramatically decreased to $49.9 \%$ of that on $\mathrm{p}\left(\mathrm{DMAEMA}^{+}\right)$brush coatings. When the content of MPC was up to $50 \mathrm{wt} \%$, the BSA adsorption amount decreased to $29.3 \%$. As reported in the process of non-selective protein adsorption on material surface, the hydrophobic interactions played an important role. ${ }^{47}$ The effective reduction of BSA adsorption could be due to the presence of MPC in the brush coating. The high hydrophilic property of MPC groups with net neutral charges on the surface could be due to protein resistance. It is widely accepted that MPC coating could take up quantity of water to resist protein adhesion. . $^{4,49}$

\section{Antibacterial activity tests} Initial bacterial adhesion

The first 24 hours is known as "decisive period" after biomedical device implantation to resist bacterial adhesion. Adhesion is the first step of biofilm formation and the best moment for the action of anti-adhesive and anti-biofilm compounds. ${ }^{50}$ To determine the anti-adhesion property of the copolymer brushes, waterborne test was carried out on coatings modified and pristine PDMS. After incubating with $S$. aureus suspension for 15 seconds, live/dead staining method and fluorescence microscopy images were used to determine the ratio of live and dead bacteria on the surfaces. As indicated in Figure 5, pristine and p (DMAEMA ${ }^{+}$) brush-coated PDMS were very easy for bacterial adhesion (the live/dead bacteria cell density $\sim 9.3 \times 10^{5} / 5.2 \times 10^{3}$ and $5.4 \times 10^{5} / 4.8 \times 10^{4}$ cells per $\mathrm{mm}^{2}$, respectively). The difference was that a small amount of bacteria (red fluorescence) had been killed by quaternary ammonium salt in the coating. For the $\mathrm{p}$ (DMAEMA ${ }^{+}$-co-MPC) copolymer brushes, the number of adhering $S$. aureus was significantly decreased (the live/ dead bacteria cell density $\sim 3.3 \times 10^{4} / 2.3 \times 10^{3}, 1.4 \times 10^{4} / 1.8 \times 10^{3}$, and $630 / 80$ cells per $\mathrm{mm}^{2}$, respectively). Furthermore, there was almost no $S$. aureus adhesion on the surface of the $\mathrm{p}$ (DMAEMA $\left.{ }^{+}-c o-0.50 \mathrm{MPC}\right)$ copolymer coating indicating the nonfouling property of MPC constitution. As discussed in the previous section on BSA, the anti-adhesion mechanism was that quantity of free water was absorbed by MPC constituent to resist bacterial adhesion.

\section{Biofilm inhibition assay}

Approximately $10^{6}$ colony forming units $/ \mathrm{mL}$ was used to initiate the formation of $S$. aureus biofilm on each PDMS material, and then the biofilm was detected by 


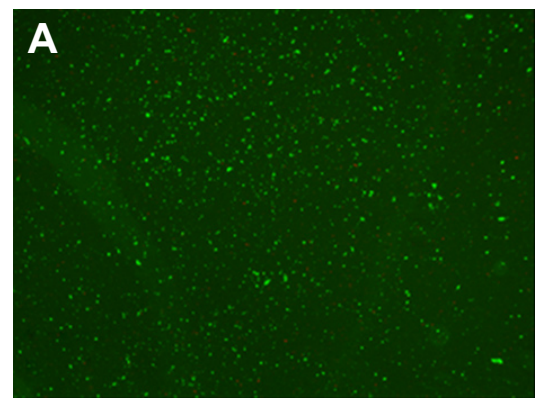

D

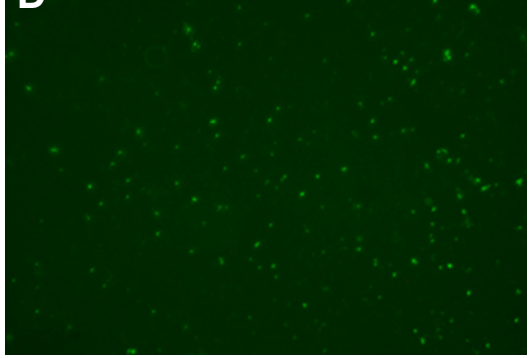

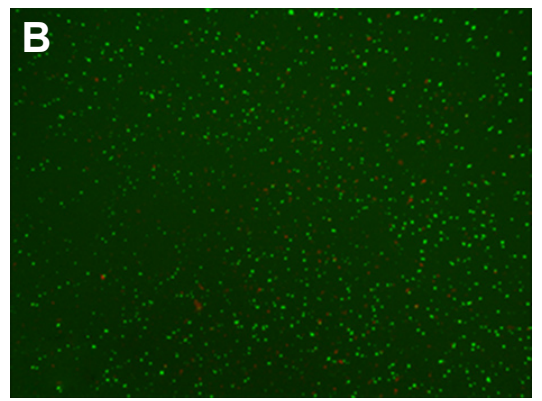
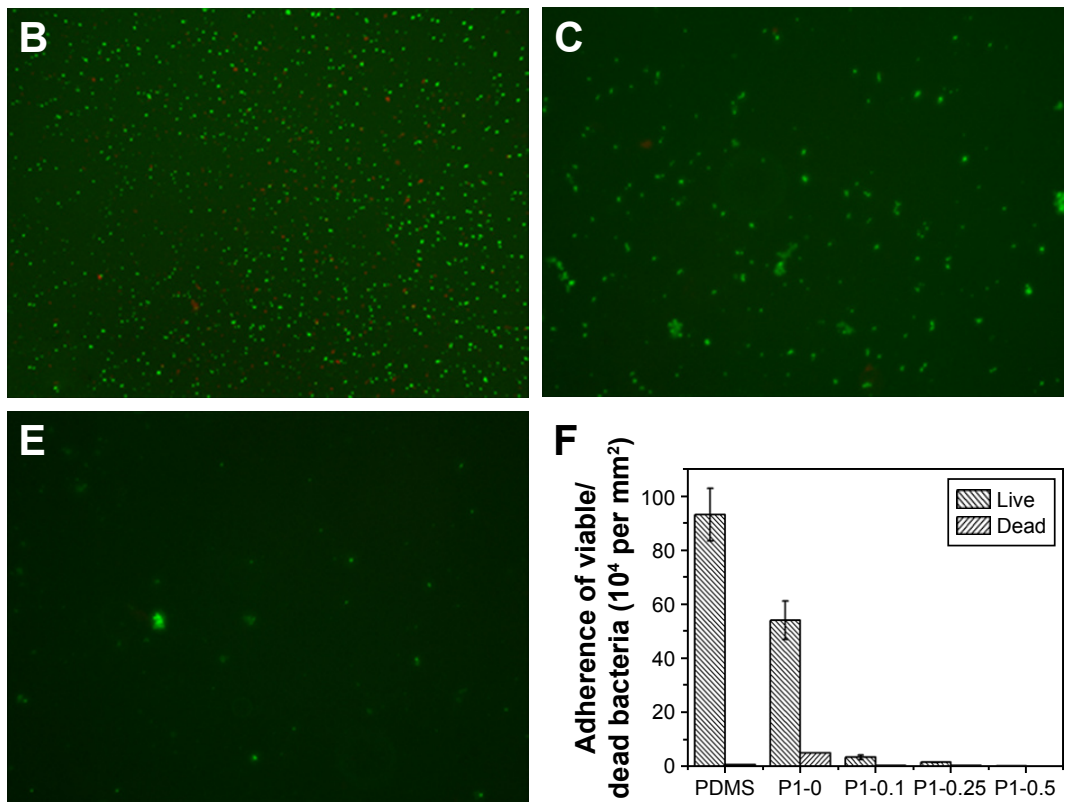

Figure 5 Fluorescent microscopy images of live/dead staining of $S$. aureus adhesions.

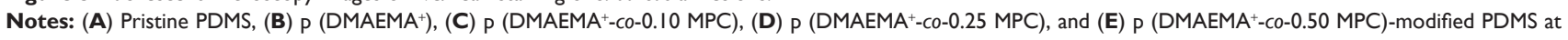
15 seconds. The green color indicates live bacteria, and the red color indicates dead bacteria, under fluorescence microscopy (the magnification is I0X). (F) Adherence of the live/dead bacteria cell density on the surfaces.

Abbreviations: S. aureus, Staphylococcus aureus; PDMS, poly(dimethyl siloxane); P (DMAEMA+-co-MPC), (2-(dimethylamino)-ethyl methacrylate-co-2-methacryloyloxyethyl phosphorylcholine); MPC, 2-methacryloyloxyethyl phosphorylcholine; DMAEMA, 2-(dimethylamino)-ethyl methacrylate.

live/dead two-color fluorescence staining method at 24 or 72 hours of incubation. As shown in Figure 6, biofilm production on PDMS and p (DMAEMA $\left.{ }^{+}\right)$brush-coated PDMS had increased significantly by 24 hours compared with that on $\mathrm{p}\left(\mathrm{DMAEMA}^{+}-\mathrm{co}-\mathrm{MPC}\right)$ copolymer brush coatings. A significant amount of viable bacteria (stained green) adhesion could be seen on PDMS, which was almost formed into a layer (the live/dead bacteria cell
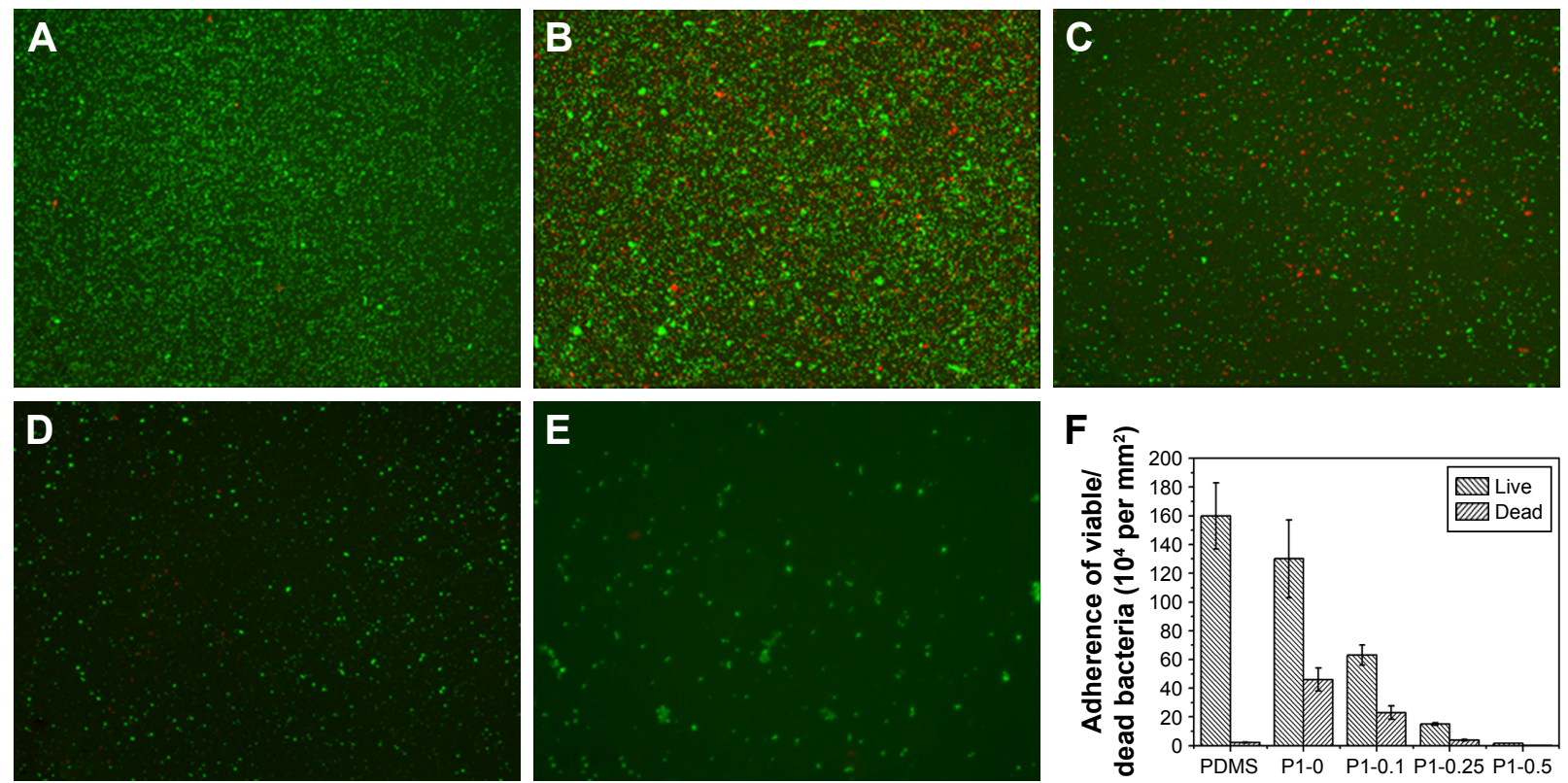

Figure 6 Fluorescent microscopy images of live/dead staining of $S$. aureus.

Notes: (A) Pristine PDMS, (B) p (DMAEMA $)$, (C) p (DMAEMA+-co-0.10 MPC), (D) p (DMAEMA ${ }^{+}-c o-0.25$ MPC), and (E) p (DMAEMA ${ }^{+}$-co-0.50 MPC)-modified PDMS at 24 hours. The green color indicates live bacteria, and the red color indicates dead bacteria, under fluorescence microscopy (the magnification is $10 \times$ ). (F) Adherence of the live/dead bacteria cell density on the surfaces.

Abbreviations: S. aureus, Staphylococcus aureus; PDMS, poly(dimethyl siloxane); p (DMAEMA+-co-MPC), (2-(dimethylamino)-ethyl methacrylate-co-2-methacryloyloxyethyl phosphorylcholine); MPC, 2-methacryloyloxyethyl phosphorylcholine; DMAEMA, 2-(dimethylamino)-ethyl methacrylate. 
density $\sim 1.6 \times 10^{6} / 2.2 \times 10^{4}$ cells per $\mathrm{mm}^{2}$ ). Meanwhile, the number of the bacteria adhered on the $\mathrm{p}\left(\mathrm{DMAEMA}^{+}\right)$ brushes was less than that on PDMS. Furthermore, a large number of $S$. aureus were stained red showing death of the bacteria (the live/dead bacteria cell density $\sim 1.3 \times 10^{6} / 4.6 \times 10^{5}$ cells per $\mathrm{mm}^{2}$ ). As for the copolymer brush-coated PDMS, there was a significant reduction of the bacterial number on $\mathrm{p}\left(\mathrm{DMAEMA}^{+}\right)$brush-modified PDMS (the live/dead bacteria cell density $\sim 6.3 \times 10^{5} / 2.3 \times 10^{5}, 1.5 \times 10^{5} / 3.8 \times 10^{4}$, and $1.6 \times 10^{4} / 2.0 \times 10^{3}$ cells per $\mathrm{mm}^{2}$, respectively). As reported in the literature, the resistance of bacteria adhesion by the p (DMAEMA+-co-MPC) copolymer brush-coated surfaces can be owing to high surface hydrophilicity and low surface energy. ${ }^{30,51}$ Moreover, the number of adhered bacteria decreased greatly with the increase of MPC in the brushes, and the bacteria had been partially killed on contact with $\mathrm{DMAEMA}^{+}$constitution. Comparing with the adhesion of $S$. aureus at the first 15 seconds, it could be concluded that the quantitative differences become larger and larger. With time, the adhered $S$. aureus proliferated very fast in the Luria-Bertani broth nutrition environment. The large number of bacteria almost formed into a monolayer on PDMS and $\left(\mathrm{DMAEMA}^{+}\right)$brushes, which will form into biofilm.

After incubation for 72 hours, high density of small bacterial colonies and bacteria with stained green (viable bacteria) spread on the PDMS surface to form patchy biofilms (Figure 7). Owing to natural apoptosis, there were also dead cells (stained red) on the surface (the live/dead bacteria cell density $\sim 2.9 \times 10^{6} / 1.8 \times 10^{4}$ cells per $\mathrm{mm}^{2}$ ). As for the PDMS coated with $\mathrm{p}\left(\mathrm{DMAEMA}^{+}\right)$brushes, after 72 h of incubation with the $S$. aureus suspension, the surface was covered with large number of bacteria stained with red fluorescence (Figure 7B) (the live/dead bacteria cell density $\sim 1.4 \times 10^{6} / 8.6 \times 10^{5}$ cells per $\mathrm{mm}^{2}$ ). Moreover, most of bacteria died indicating the high bactericidal property of the brushes and the absence of anti-adhesive property of such brush coating. There were also a large number of viable bacterial adhering on the $\mathrm{p}\left(\mathrm{DMAEMA}^{+}\right)$brush surface, indicative of the loss of bactericidal property as the closely adhered bacterial cadavers acted as barrier between $\mathrm{DMAEMA}^{+}$and viable bacteria. The bacteria density on the $\mathrm{p}\left(\mathrm{DMAEMA}^{+}-\right.$ co-MPC) copolymer brush surface was also found to be significantly less than that on the pristine PDMS (the live/ dead bacteria cell density $\sim 7.1 \times 10^{5} / 4.6 \times 10^{5}, 1.9 \times 10^{5} / 6.7 \times 10^{4}$, and $1.7 \times 10^{4} / 1.6 \times 10^{3}$ cells per $\mathrm{mm}^{2}$, respectively). It was noteworthy that the number of adhesion bacteria on the copolymer brush surface decreased greatly with an increase in MPC in the brushes, although the killing efficiency was not as high as single $\mathrm{p}\left(\mathrm{DMAEMA}^{+}\right)$brushes.

The morphology and distribution bacteria on the surfaces of coating modified and pristine PDMS were examined by scanning electron microscope after incubating with bacterial
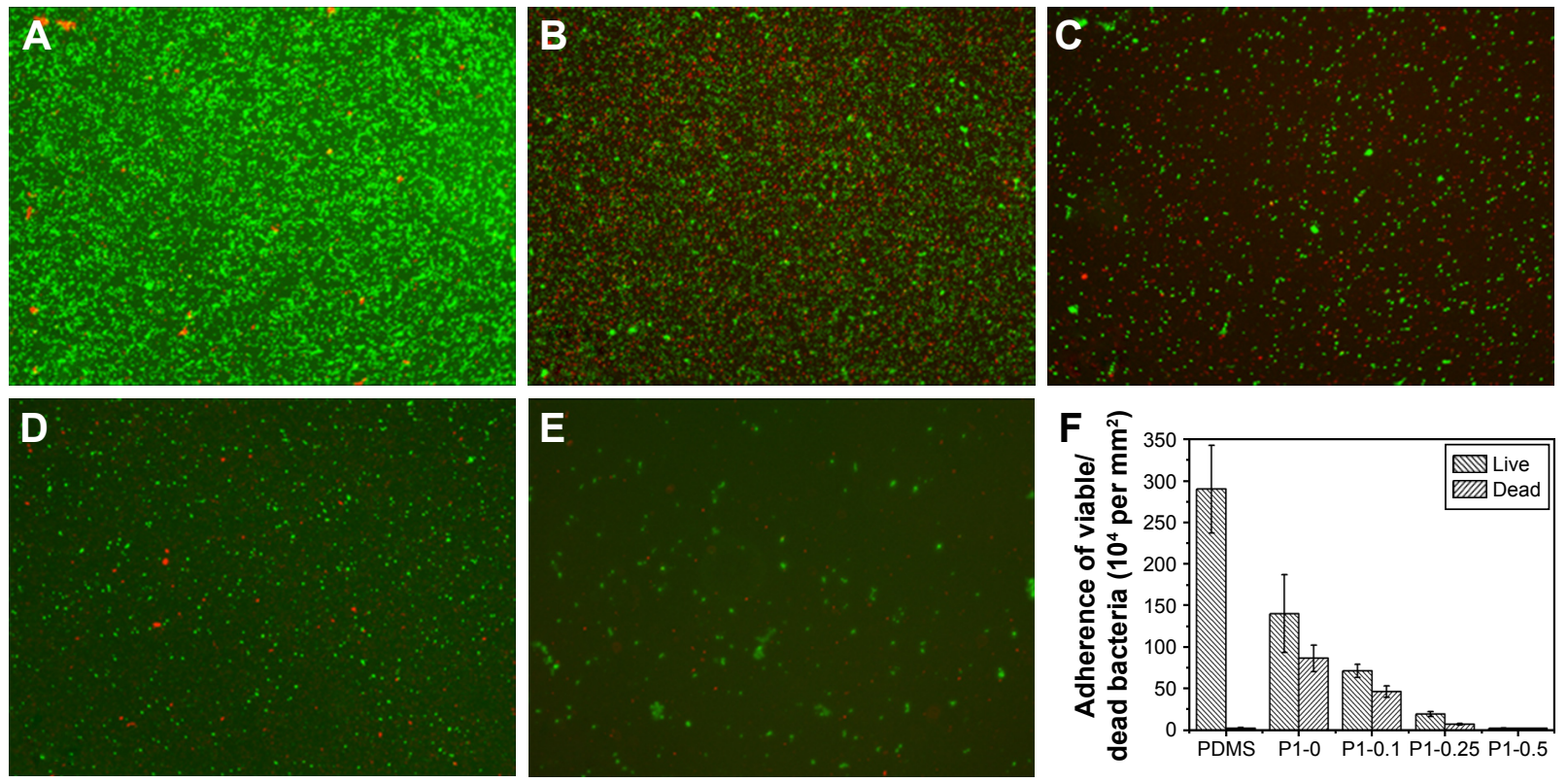

Figure 7 Fluorescent microscopy images of live/dead staining of $S$. aureus.

Notes: (A) Pristine PDMS, (B) P (DMAEMA+), (C) P (DMAEMA ${ }^{+}$-co-0.10 MPC), (D) P (DMAEMA+-co-0.25 MPC), and (E) P (DMAEMA+-co-0.50 MPC)-modified PDMS at 72 hours. The green color indicates live bacteria, and the red color indicates dead bacteria, under fluorescence microscopy (the magnification is $10 \times$ ). (F) Adherence of the live/dead bacteria cell density on the surfaces.

Abbreviations: S. aureus, Staphylococcus aureus; PDMS, poly(dimethyl siloxane); P (DMAEMA+-co-MPC), (2-(dimethylamino)-ethyl methacrylate-co-2-methacryloyloxyethyl phosphorylcholine); MPC, 2-methacryloyloxyethyl phosphorylcholine; DMAEMA, 2-(dimethylamino)-ethyl methacrylate. 
suspension. It showed that bacteria PDMS could easily adhere on PDMS surface and almost form a layer of bacteria, as seen in Figure 8 (the bacteria cell density $\sim 2.4 \times 10^{5}$ cells per $\mathrm{mm}^{2}$ ). Bacteria adhesion and proliferation led to a rapid increase in the bacteria number, which packed and accumulated into colonies and early form of biofilm. What is more, the adhering of bacteria on the PDMS surface had clear outline and good shape, indicating the survival of $S$. aureus. The bacteria adhered on $\mathrm{p}\left(\mathrm{DMAEMA}^{+}\right)$brush surface showed unclear outline, indicating the death of bacteria (the bacteria cell density $\sim 1.3 \times 10^{5}$ cells per $\mathrm{mm}^{2}$ ). Furthermore, only a small amount of bacteria adhered on the $\mathrm{p}\left(\mathrm{DMAEMA}^{+}-\mathrm{co}\right.$-MPC) brush coating (the bacteria cell density $\sim 3.1 \times 10^{4}, 1.3 \times 10^{4}$, and $2.7 \times 10^{3}$ cells per $\mathrm{mm}^{2}$, respectively).

Although it has not been fully elucidated the adhesion mechanism of bacteria on material surface, the interactions between material and bacteria composed of specific receptoradhesion interactive forces, hydrophobic interactions, van der Waals forces, and electrostatic forces. ${ }^{52}$ There are mainly two stages in the process of bacterial adhesion: the initial, reversible, and rapid interaction and the irreversible stage based on specific and nonspecific interactions. Though there was still some $S$. aureus adhered on p (DMAEMA ${ }^{+}$-co-MPC) copolymer brush surface, most of which might be on the reversible adhesion stage. As shown in Figures $6 \mathrm{C}-\mathrm{E}$ and $7 \mathrm{C}-\mathrm{E}$, the adhered $S$. aureus on the p (DMAEMA ${ }^{+}$-co-MPC) copolymer brush surface were almost in survival status (stained green). By contrast, the adhered $S$. aureus on the p (DMAEMA $\left.{ }^{+}\right)$brush surface were almost bacteria corpse (stained red), which were in irreversible adhesion. It is assumed that the $\mathrm{DMAEMA}^{+}$in both $\mathrm{p}\left(\mathrm{DMAEMA}^{+}\right.$-co-MPC) copolymer and $\mathrm{p}\left(\mathrm{DMAEMA}^{+}\right)$ brushes could exhibit high efficient bactericidal function. In order to confirm this assumption, a simple way was to monitor the bacterial concentration in the solution.

\section{Bactericidal activity test}

A plot of survival versus contact time was drawn to analyze the bactericidal activity of the brush coatings by mean of contact killing and/or releasing methods. As indicated in Figure 9, the number of $S$. aureus in the suspension decreased by $7 \%$ after 24 hours of incubation with pristine PDMS, which might be due to natural apoptosis. Meanwhile, for the brush coating, the number of viable $S$. aureus decreased gradually. The sterilization rate of the $\mathrm{p}\left(\mathrm{DMAEMA}^{+}\right)$brush surface was faster than the $\mathrm{p}$ (DMAEMA ${ }^{+}$-co-MPC) copolymer brush surface. After 4 hours of exposure, the number of viable S. aureus decreased by more than $46 \%$ for the $\mathrm{p}\left(\mathrm{DMAEMA}^{+}\right)$ brush surface and $33 \%-42 \%$ for the p (DMAEMA ${ }^{+}$-co-MPC) copolymer brush surface. There were mainly two reasons for the reduction of bactericidal property of the $\mathrm{p}\left(\mathrm{DMAEMA}^{+}-\right.$ co-MPC) copolymer brush surface. On one hand, the increase of MPC constituent reduced the contacting of $S$. aureus to
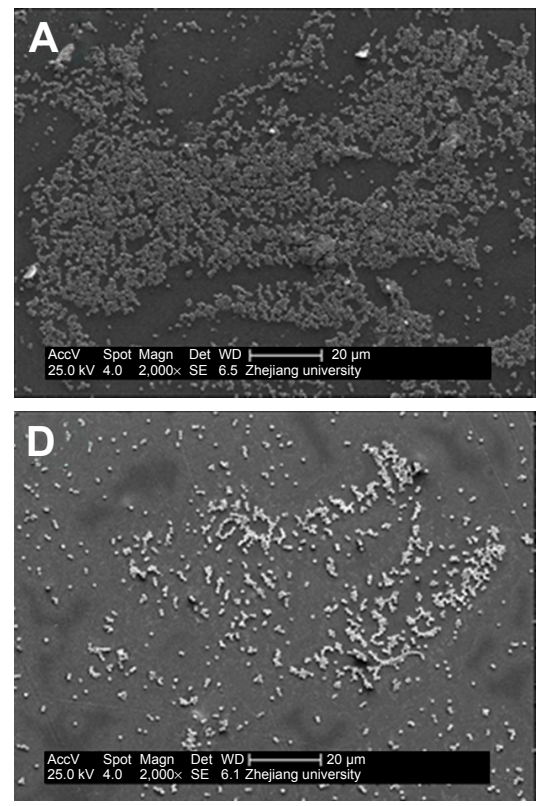
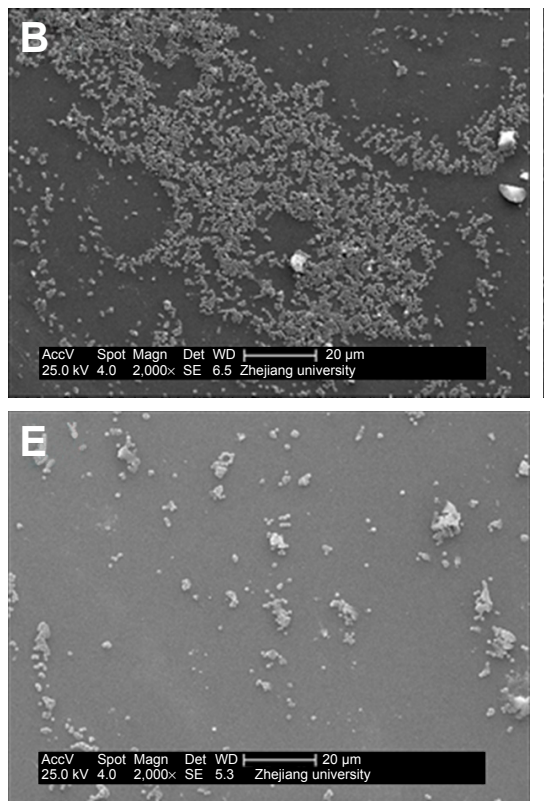
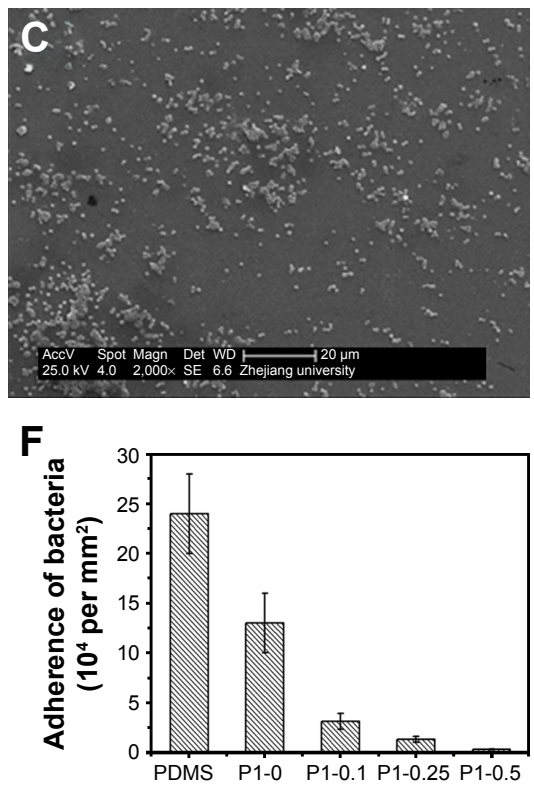

Figure 8 SEM images.

Notes: (A) Pristine PDMS, (B) p (DMAEMA ${ }^{+}$), (C) p (DMAEMA+'-co-0.10 MPC), (D) p (DMAEMA+-co-0.25 MPC), and (E) p (DMAEMA+-co-0.50 MPC)-modified PDMS after exposure to waterborne $S$. aureus. (F) Adherence of the bacteria cell density on the surfaces.

Abbreviations: SEM, scanning electron microscope; PDMS, poly(dimethyl siloxane); (DMAEMA+-co-MPC), (2-(dimethylamino)-ethyl methacrylate-co-2-methacryloyloxyethyl phosphorylcholine); S. aureus, Staphylococcus aureus; MPC, 2-methacryloyloxyethyl phosphorylcholine; DMAEMA, 2-(dimethylamino)-ethyl methacrylate. 


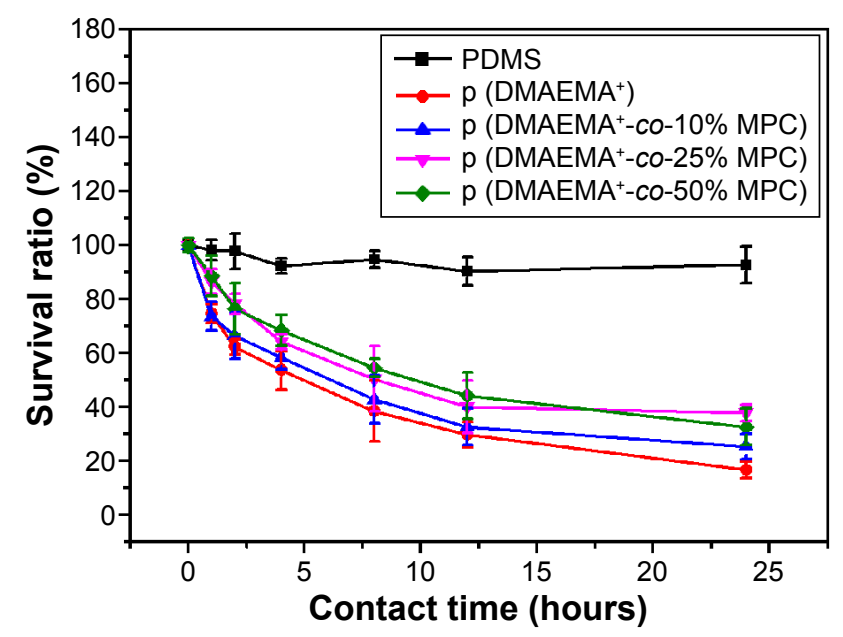

Figure 9 Changes of the viable $S$. aureus cells after exposure to various surfaces. Notes: Pristine PDMS, p (DMAEMA ${ }^{+}$), p (DMAEMA ${ }^{+}-c 0-0.10$ MPC), p (DMAEMA+co-0.25 MPC), and $p$ (DMAEMA ${ }^{+}$-co-0.50 MPC)-modified PDMS for 24 hours.

Abbreviations: S. aureus, Staphylococcus aureus; PDMS, poly(dimethyl siloxane); P (DMAEMA+-co-MPC), (2-(dimethylamino)-ethyl methacrylate-co-2-methacryloyloxyethyl phosphorylcholine); MPC, 2-methacryloyloxyethyl phosphorylcholine; DMAEMA, 2-(dimethylamino)-ethyl methacrylate.

the material surface due to the nonfouling property of MPC, which led to the formation of hydrophilic coating on the substrate. However, the existing of MPC decreased the density of DMAEMA ${ }^{+}$in the copolymer brushes. At 24 hours, more than $8 \%$ of the bacteria had been killed for the $\mathrm{p}\left(\mathrm{DMAEMA}^{+}\right)$ brushes and $67 \%-75 \%$ for the $\mathrm{p}$ (DMAEMA ${ }^{+}$-co-MPC) copolymer brush surface.

These results further demonstrated that the quaternary ammonium salt grafted-PDMS surface showed high sterilization efficiency against $S$. aureus. The antimicrobial activity mainly originated from the hydrophobic chains to disrupt the cell membranes and to increase cell permeability. The hydrophobic segment provided by the long alkyl chain is compatible with bacterial cytoplasmic membrane in the lipid bilayer. The positively charged PQAs firstly adsorbed onto the negatively charged bacterial surfaces and diffused though the cell wall. Then, PQAs bound to and disrupted the cytoplasmic membrane, which led to the loss of cytoplasmic constituents and the death of bacteria. As shown in Figures 5-8, the number of adhered $S$. aureus on the copolymer $\mathrm{p}$ (DMAEMA ${ }^{+}-\mathrm{co}-\mathrm{MPC}$ ) brush coating was much less than that on the $\mathrm{p}\left(\mathrm{DMAEMA}^{+}\right)$brush coating. However, the bactericidal function of copolymer coatings was not much lower than of $p\left(\right.$ DMAEMA $\left.^{+}\right)$brush coatings. It could be concluded that the $\mathrm{p}$ (DMAEMA+-co-MPC) brush coating could smart "capture", kill bacteria, and then release bacteria corpse. The bacterial release ability mainly could be due to the nonfouling function of zwitterionic MPC constitution. So, the surface-initiated RAFT polymerization method achieved the design of smart nonfouling, bactericidal, and bacteria corpse releasing multifunction.

\section{Cytotoxicity of the material surfaces}

Although PQAs had a high bactericidal function, which used to modify the surface of biomaterials, the cytotoxicity should also be considered. To evaluate the cytocompatibility of the antibacterial copolymer brush surfaces, growth and proliferation of HLECs on the surfaces were investigated. As shown in Figure 10, over a period of 24 hours, CCK-8 assay was applied to quantitative assessment of the cytotoxicity. The cell viability of the brush coatings exceeded $80 \%$ of that on TCPS, which suggested the low cytotoxicity and good biocompatibility. However, as for the $\mathrm{p}\left(\mathrm{DMAEMA}^{+}\right)$ brush coating, the cell viability was very low ( $59 \%$ of that on TCPS), which was ascribed to the cytotoxicity of PQAs..$^{53,54}$ In comparison, the MPC component in the brushes obviously increased cytocompatibility of the antibacterial surfaces.

The adhesion and morphology of HLECs were also evaluated after the FDA staining method, as shown in Figure 11. After 24 hours of incubation, there were many HLECs cultured on PDMS and $\mathrm{p}\left(\mathrm{DMAEMA}^{+}\right)$brush coating, which maintained normal spreading morphology (Figure 11A and $\mathrm{B}$ ) (the adherent cell density $\sim 6.3 \times 10^{3}$ and $3.4 \times 10^{3}$ cells per $\mathrm{mm}^{2}$, respectively). It was suggested that these surfaces were suitable for adhesion and growth of HLECs. The number of HLECs adhered on the p (DMAEMA ${ }^{+}-\mathrm{Do}^{-}$ MPC) brush coating was much less than that on the PDMS

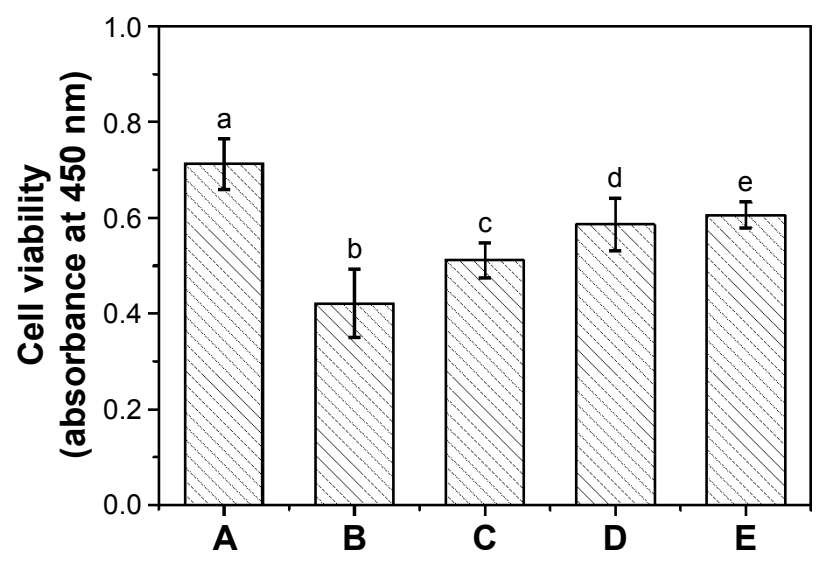

Figure 10 The cell viability assay of HLECs cultured on various surfaces.

Notes: (A) TCPS, (B) P (DMAEMA ${ }^{+}$), (C) P (DMAEMA ${ }^{+}-c 0-0.10$ MPC), (D) $\mathrm{P}$ (DMAEMA ${ }^{+}-c o-0.25 \mathrm{MPC}$ ), and (E) P (DMAEMA $\left.{ }^{+}-c o-0.50 \mathrm{MPC}\right)$-modified PDMS for 24 hours. The absorbance of the diluted Cell Counting Kit solution has been deducted from each data point, and the statistical significance is indicated by different letters $(P<0.05)$.

Abbreviations: HLECs, human lens epithelial cells; TCPS, tissue culture plates; P (DMAEMA+-co-MPC), (2-(dimethylamino)-ethyl methacrylate-co-2methacryloyloxyethyl phosphorylcholine); PDMS, poly(dimethyl siloxane); MPC, 2-methacryloyloxyethyl phosphorylcholine; DMAEMA, 2-(dimethylamino)-ethyl methacrylate. 

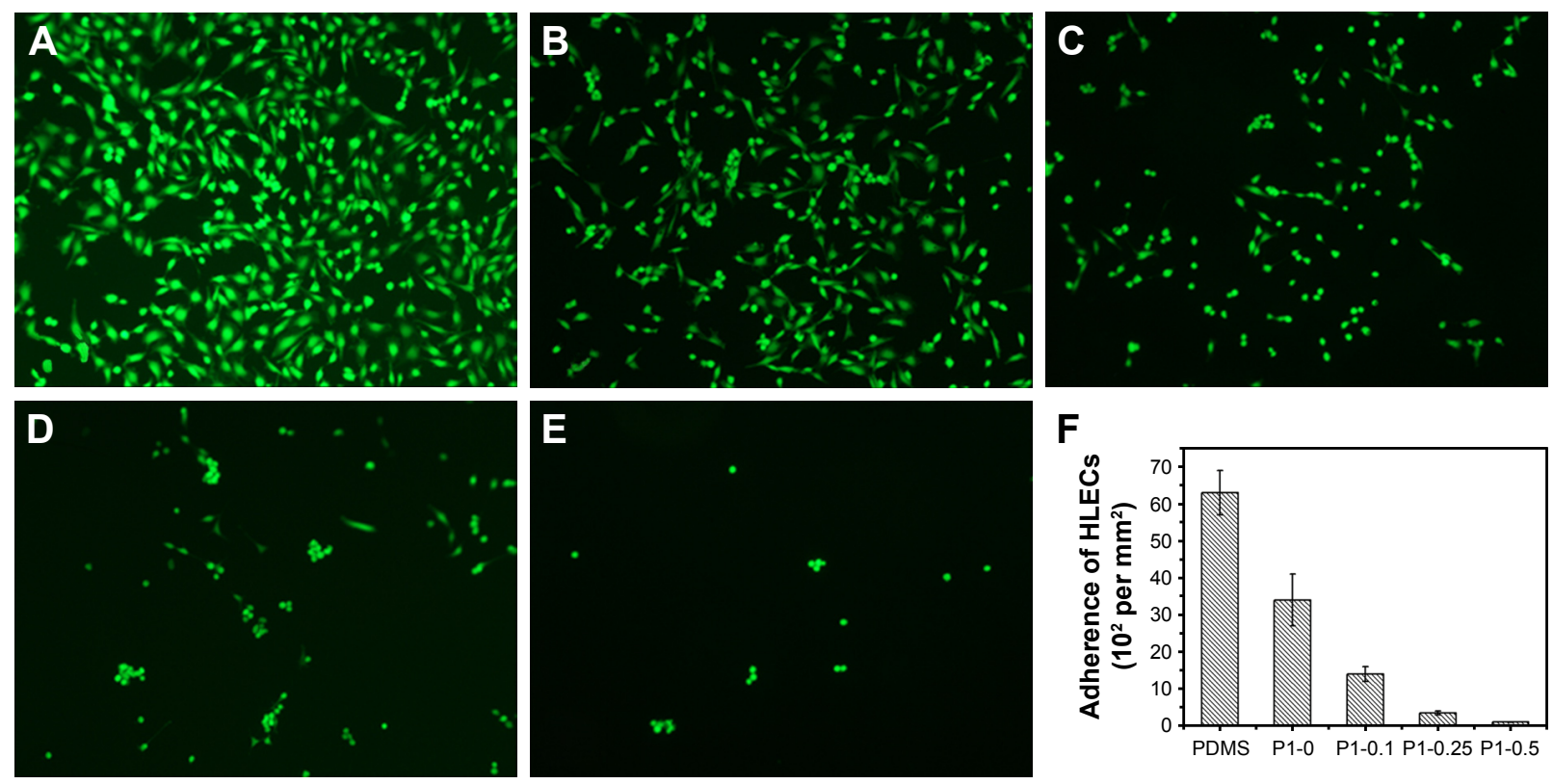

Figure II Growth and morphology of HLECs stained with FDA after 24 hours of incubation on various surfaces.

Notes: (A) Pristine PDMS, (B) p (DMAEMA ${ }^{+}$), (C) p (DMAEMA+-co-0.10 MPC), (D) P (DMAEMA+-co-0.25 MPC), (E) P (DMAEMA+-co-0.50 MPC)-modified PDMS and, (F) adherence of the HLECs density on the surfaces. The magnification is I0X.

Abbreviations: HLECs, human lens epithelial cells; FDA, fluorescein diacetate; TCPS, tissue culture plates; PDMS, poly(dimethyl siloxane); P (DMAEMA + -co-MPC), (2-(dimethylamino)-ethyl methacrylate-co-2-methacryloyloxyethyl phosphorylcholine); MPC, 2-methacryloyloxyethyl phosphorylcholine; DMAEMA, 2-(dimethylamino)-ethyl methacrylate.

and $\mathrm{p}\left(\mathrm{DMAEMA}^{+}\right)$brush coatings (the adherent cell density $\sim 1.4 \times 10^{3}, 340$, and 96 cells per $\mathrm{mm}^{2}$, respectively). This could be owing to the nonfouling function of the zwitterionic MPC component. The remaining HLECs after cataract surgery may proliferate and form Elschnig pearls on the capsule's surface and also onto the IOL surface and eventually resulted in posterior capsule opacification. The decrease in the number of HLECs adhering on IOL can inhibit the formation of multicellular secondary membrane or fibrosis on the posterior capsule and eventually restrain the occurring of posterior capsule opacification.

\section{Conclusion}

In the present study, a novel p (DMAEMA+-co-MPC) copolymer brush was synthesized by "grafting from" surfaceinitiated RAFT polymerization method. Spectroscopic ellipsometry, AFM, and WCA measurements confirmed each modified step. Surface hydrophilicity and morphology tests indicted the low roughness and high hydrophilicity of coatings. The $\mathrm{p}$ (DMAEMA ${ }^{+}-\mathrm{co}$-MPC) copolymer brush surface exhibited high nonfouling activity against BSA protein, HLECs, and $S$. aureus as compared to the pristine and $\mathrm{p}\left(\mathrm{DMAEMA}^{+}\right)$brush coating-modified PDMS surfaces. The brush-modified surface also exhibited high bactericidal efficiency toward $S$. aureus as revealed by measurements of bacteria live/dead staining and shake-flask culture methods.
Biofilm inhibition assay showed that copolymer brush surface was very effective in inhibiting bacterial adhesion and biofilm formation on contact with $S$. aureus in nutrient environment from 15 seconds to 72 hours. Brush coating could continuously "capture" and kill bacteria, and "released" bacteria corpse away from the surface. Thus, the complexity of nonfouling property owing to MPC groups with net neutral charge and high hydrophilic property and the efficient bactericidal effect of DMAEMA ${ }^{+}$had many advantages in inhibiting biofilm formation. The smart antibacterial surface also had low cytotoxicity, which will be used for IOL modification and other biomaterial modification.

\section{Acknowledgments}

National Natural Science Foundation of China (51403158, 81271703 ) and the International Scientific \& Technological Cooperation Projects (2012DFB30020) are greatly acknowledged by the authors.

\section{Disclosure}

The authors report no conflicts of interest in this work.

\section{References}

1. Kadry AA, Fouda SI, Shibl AM, Abu El-Asrar AA. Impact of slime dispersants and anti-adhesives on in vitro biofilm formation of Staphylococcus epidermidis on intraocular lenses and on antibiotic activities. J Antimicrob Chemother. 2009;63(3):480-484. 
2. Wang B, Lin Q, Jin T, et al. Surface modification of intraocular lenses with hyaluronic acid and lysozyme for the prevention of endophthalmitis and posterior capsule opacification. $R S C A d v$. 2015;5:3597-3604.

3. Verbraeken H. Treatment of postoperative endophthalmitis. Ophthalmologica. 1995;209(3):165-171.

4. Kresloff MS, Castellarin AA, Zarbin MA. Endophthalmitis. Surv Ophthalmol. 1998;43(3):193-224.

5. Aaberg TM Jr, Flynn HW Jr, Schiffman J, Newton J. Nosocomial acute onset postoperative endophthalmitis survey. A 10-year review of incidence and outcomes. Ophthalmology. 1998;105(6):1004-1010.

6. McCoy CP, Craig RA, McGlinchey SM, Carson L, Jones DS, Gorman SP. Surface localisation of photosensitisers on intraocular lens biomaterials for prevention of infectious endophthalmitis and retinal protection. Biomaterials. 2012;33(32):7952-7958.

7. Parsons C, Jones DS, Gorman SP. The intraocular lens: challenges in the prevention and therapy of infectious endophthalmitis and posterior capsular opacification. Expert Rev Med Devices. 2005;2(2):161-173.

8. Fazly Bazzaz BS, Jalalzadeh M, Sanati M, Zarei-Ghanavati S, Khameneh B. Biofilm formation by Staphylococcus epidermidis on foldable and rigid intraocular lenses. Jundishapur J Microbiol. 2014; 7(5): 10020

9. Wang BL, Wang JL, Li DD, Ren KF, Ji J. Chitosan/poly (vinyl pyrollidone) coatings improve the antibacterial properties of poly(ethylene terephthalate). Appl Surf Sci. 2012;258(20):7801-7808.

10. Costerton JW, Stewart PS, Greenberg EP. Bacterial biofilms: a common cause of persistent infections. Science. 1999;284(5418):1318-1322.

11. Lichter JA, Rubner MF. Polyelectrolyte multilayers with intrinsic antimicrobial functionality: the importance of mobile polycations. Langmuir. 2009;25(13):7686-7694.

12. Davies DG, Parsek MR, Pearson JP, Iglewski BH, Costerton JW, Greenberg EP. The involvement of cell-to-cell signals in the development of a bacterial biofilm. Science. 1998;280(5361):295-298.

13. Besinis A, De Peralta T, Handy RD. Inhibition of biofilm formation and antibacterial properties of a silver nano-coating on human dentine. Nanotoxicology. 2014;8(7):745-754.

14. Lu Y, Slomberg DL, Schoenfisch MH. Nitric oxide-releasing chitosan oligosaccharides as antibacterial agents. Biomaterials. 2014;35(5): 1716-1724.

15. Wang R, Neoh KG, Kang ET. Integration of antifouling and bactericidal moieties for optimizing the efficacy of antibacterial coatings. J Colloid Interface Sci. 2015;438:138-148.

16. Wei K, Wang L, Li L, Zheng SX. Synthesis and characterization of bead-like poly(N-isopropylacrylamide) copolymers with double decker silsesquioxane in the main chains. Polymer Chem. 2015;6:256-269.

17. Jo YK, Seo JH, Choi BH, et al. Surface-independent antibacterial coating using silver nanoparticle-generating engineered mussel glue. ACS Appl Mater Interfaces. 2014;6(22):20242-20253.

18. Li J, Wang G, Meng Q, Ding C, Jiang H, Fang Y. A biomimetic nano hybrid coating based on the lotus effect and its anti-biofouling behaviors. Appl Surf Sci. 2014;315:407-414.

19. Hadjesfandiari N, Yu K, Mei Y, Kizhakkedathu JN. Polymer brushbased approaches for the development of infection-resistant surfaces. J Mater Chem B. 2014;2(31):4968-4978.

20. Colilla M, Martinez-Carmona M, Sanchez-Salcedo S, Luisa RuizGonzalez M, Gonzalez-Calbet JM, Vallet-Regi M. A novel zwitterionic bioceramic with dual antibacterial capability. J Mater Chem B. 2014;2: 5639-5651.

21. Morra M, Cassineli C. Non-fouling properties of polysaccharide-coated surfaces. J Biomater Sci Polym Ed. 1999;10(10):1107-1124.

22. Yang C, Ding X, Ono RJ, et al. Brush-like polycarbonates containing dopamine, cations, and PEG providing a broad-spectrum, antibacterial, and antifouling surface via one-step coating. Adv Mater. 2014;26(43): 7346-7351.

23. King A, Chakrabarty S, Zhang W, et al. High antimicrobial effectiveness with low hemolytic and cytotoxic activity for PEG/quaternary copolyoxetanes. Biomacromolecules. 2014;15(2):456-467.
24. Alpatova A, Kim ES, Sun X, Hwang G, Liu Y, El-Din MG. Fabrication of porous polymeric nanocomposite membranes with enhanced antifouling properties: effect of casting composition. J Membr Sci. 2013; 444:449-460.

25. Wang B, Ren K, Chang H, Wang J, Ji J. Construction of degradable multilayer films for enhanced antibacterial properties. ACS Appl Mater Interfaces. 2013;5(10):4136-4143.

26. Zhu LJ, Zhu LP, Yi Z, Jiang JH, Zhu BK, Xu YY. Hemocompatible and antibacterial porous membranes with heparinized copper hydroxide nanofibers as separation layer. Colloids Surf B Biointerfaces. 2013;110: $36-44$.

27. Zhang Q, Tang X, Wang T, Yu F, Guo W, Pei M. Thermo-sensitive zwitterionic block copolymers via ATRP. RSC Adv. 2014;4:24240-24247.

28. Rajabzadeh S, Sano R, Ishigami T, Kakihana Y, Ohmukai Y, Matsuyama H. Preparation of hydrophilic vinyl chloride copolymer hollow fiber membranes with antifouling properties. Appl Surf Sci. 2015; 324:718-724

29. Saeki D, Tanimoto T, Matsuyama H. Prevention of bacterial adhesion on polyamide reverse osmosis membranes via electrostatic interactions using a cationic phosphorylcholine polymer coating. Colloids Surf A Physicochem Eng Asp. 2014;443:171-176.

30. Fuchs AV, Ritz S, Putz S, Mailander V, Landfester K, Ziener U. Bioinspired phosphorylcholine containing polymer films with silver nanoparticles combining antifouling and antibacterial properties. Biomater Sci. 2013;1:470-477.

31. Li M, Neoh KG, Xu LQ, et al. Surface modification of silicone for biomedical applications requiring long-term antibacterial, antifouling, and hemocompatible properties. Langmuir. 2012;28(47):16408-16422.

32. Dong H, Huang J, Koepsel RR, Ye P, Russell AJ, Matyjaszewski K. Recyclable antibacterial magnetic nanoparticles grafted with quaternized poly(2-(dimethylamino)ethyl methacrylate) brushes. Biomacromolecules. 2011;12(4):1305-1311.

33. Zammarelli $\mathrm{N}$, Luksin $\mathrm{M}$, Raschke $\mathrm{H}$, Hergenroder $\mathrm{R}$, Weberskirch R. "Grafting-from" polymerization of PMMA from stainless steel surfaces by a RAFT-mediated polymerization process. Langmuir. 2013;29(41):12834-12843.

34. Faure E, Falentin-Daudre C, Lanero TS, et al. Functional nanogels as platforms for imparting antibacterial, antibiofilm, and antiadhesion activities to stainless steel. Adv Funct Mater. 2012;22(24):5271-5282.

35. Fadida T, Kroupitski Y, Peiper UM, Bendikov T, Sela SS, Poverenov E. Air-ozonolysis to generate contact active antimicrobial surfaces: activation of polyethylene and polystyrene followed by covalent graft of quaternary ammonium salts. Colloids Surf B Biointerfaces. 2014;122:294-300.

36. Wang JL, Zhu H, Chen GJ, et al. Controlled synthesis and self-assembly of dopamine-containing copolymer for honeycomb-like porous hybrid particles. Macromol Rapid Commun. 2014;35(11):1061-1067.

37. Wang B, Jin T, Han Y, et al. Surface-initiated RAFT polymerization of $\mathrm{p}$ (MA POSS-co-DMAEMA ${ }^{+}$) brushes on PDMS for improving antiadhesive and antibacterial properties. Int J Polymer Mater Polymer Biomater. 2015;65:55-64.

38. Wang BL, Jin TW, Han YM, et al. Bio-inspired terpolymers containing dopamine, cations and MPC: a versatile platform to construct a recycle antibacterial and antifouling surface. J Mater Chem B. 2015;3: $5501-5510$

39. Wang BL, Lin QK, Shen CH, Han YM, Tang JM, Chen H. Synthesis of MA POSS-PMMA as an intraocular lens material with high light transmittance and good cytocompatibility. RSC Adv. 2014;4: 52959-52966.

40. Li X, Cao Y, Kang G, Yu H, Liu Z. Preparation of antimicrobial nanofiltration membrane via self-polymerization of dopamine and surface grafting of PHGH. Chem J Chinese Universities. 2014;35(9):2026-2030.

41. Le XT, Doan ND, Dequivre T, Viel P, Palacin S. Covalent grafting of chitosan onto stainless steel through aryldiazonium self-adhesive layers. ACS Appl Mater Interfaces. 2014;6(12):9085-9092.

42. Bolduc OR, Correia-Ledo D, Masson JF. Electroformation of peptide self-assembled monolayers on gold. Langmuir. 2012;28(1):22-26. 
43. Imbesi PM, Finlay JA, Aldred N, et al. Targeted surface nanocomplexity: two-dimensional control over the composition, physical properties and anti-biofouling performance of hyperbranched fluoropolymerpoly(ethylene glycol) amphiphilic crosslinked networks. Polymer Chem. 2012;3:3121-3131.

44. Wang B, Liu XS, Ji Y, Ren K, Xu JP. Fast and long-acting antibacterial properties of chitosan-Ag/polyvinylpyrrolidone nanocomposite films. Carbohydr Polym. 2012;90(1):8-15.

45. Ozcam AE, Roskov KE, Spontak RJ, Genzer J. Generation of functional PET microfibers through surface-initiated polymerization. J Mater Chem. 2012;22:5855-5864.

46. Long L, Yuan X, Li Z, et al. Anti-fouling properties of polylactic acid film modified by pegylated phosphorylcholine derivatives. Mater Chem Phys. 2014;143(3):929-938

47. Sui Y, Gao X, Wang ZN, Gao C. Antifouling and antibacterial improvement of surface-functionalized poly(vinylidene fluoride) membrane prepared via dihydroxyphenylalanine-initiated atom transfer radical graft polymerizations. J Membr Sci. 2012;394-395:107-119.

48. Su YL, Li C, Zhao W, et al. Modification of polyethersulfone ultrafiltration membranes with phosphorylcholine copolymer can remarkably improve the antifouling and permeation properties. J Membr Sci. 2008;322(1):171-177.
49. Liu P, Chen Q, Li L, Lin S, Shen J. Anti-biofouling ability and cytocompatibility of the zwitterionic brushes-modified cellulose membrane. J Mater Chem B. 2014;2:7222-7231.

50. Hetrick EM, Schoenfisch MH. Reducing implant-related infections: active release strategies. Chem Soc Rev. 2006;35(9):780-789.

51. Razi F, Sawada I, Ohmukai Y, Maruyama T, Matsuyama H. The improvement of antibiofouling efficiency of polyethersulfone membrane by functionalization with zwitterionic monomers. J Membr Sci. 2012;401-402:292-299.

52. Baillif S, LeDuff F, Hartmann DJ, Kodjikian L. Staphylococcus epidermidis Biofilm formation and structural organization on different types of intraocular lenses under in vitro flow conditions. Ophthalmic Res. 2013;50(2):83-90.

53. Xu FJ, Li H, Li J, Zhang Z, Kang ET, Neoh KG. Pentablock copolymers of poly(ethylene glycol), poly((2-dimethyl amino)ethyl methacrylate) and poly(2-hydroxyethyl methacrylate) from consecutive atom transfer radical polymerizations for non-viral gene delivery. Biomaterials. 2008;29(20):3023-3033.

54. Yudovin-Farber I, Beyth N, Nyska A, Weiss EI, Golenser J, Domb AJ. Surface characterization and biocompatibility of restorative resin containing nanoparticles. Biomacromolecules. 2008;9(11):3044-3050.
International Journal of Nanomedicine

\section{Publish your work in this journal}

The International Journal of Nanomedicine is an international, peerreviewed journal focusing on the application of nanotechnology in diagnostics, therapeutics, and drug delivery systems throughout the biomedical field. This journal is indexed on PubMed Central, MedLine, CAS, SciSearch $®$, Current Contents $\AA /$ Clinical Medicine,

\section{Dovepress}

Journal Citation Reports/Science Edition, EMBase, Scopus and the Elsevier Bibliographic databases. The manuscript management system is completely online and includes a very quick and fair peer-review system, which is all easy to use. Visit http://www.dovepress.com/ testimonials.php to read real quotes from published authors. 